\title{
LIQUIDITY MANAGEMENT OF U.S. GLOBAL BANKS: INTERNAL CAPITAL MARKETS IN THE GREAT RECESSION
}

\author{
Nicola Cetorelli \\ Linda S. Goldberg \\ Working Paper 17355 \\ http://www.nber.org/papers/w17355
}

\author{
NATIONAL BUREAU OF ECONOMIC RESEARCH \\ 1050 Massachusetts Avenue \\ Cambridge, MA 02138
}

August 2011

The views expressed in this paper are those of the individual authors and do not necessarily reflect the position of the National Bureau of Economic Research, the Federal Reserve Bank of New York, or the Federal Reserve System. We appreciate the thoughtful comments of Beatrice Weber, Kristin Forbes, Jeffrey Frankel, and participants at the NBER Sloan conference at Bretton Woods New Hampshire. Address correspondences to Linda S. Goldberg, Federal Reserve Bank of NY, Research Department, 33 Liberty St, New York, N.Y. 10045. email: Linda.Goldberg@ny.frb.org or Nicola.Cetorelli@ny.frb.org .We thank Leslie Shen and Benjamin Mandel for excellent research assistance.

NBER working papers are circulated for discussion and comment purposes. They have not been peerreviewed or been subject to the review by the NBER Board of Directors that accompanies official NBER publications.

(C) 2011 by Nicola Cetorelli and Linda S. Goldberg. All rights reserved. Short sections of text, not to exceed two paragraphs, may be quoted without explicit permission provided that full credit, including (C) notice, is given to the source. 
Liquidity management of U.S. global banks: Internal capital markets in the great recession Nicola Cetorelli and Linda S. Goldberg

NBER Working Paper No. 17355

August 2011

JEL No. F3,G15,G21

\begin{abstract}
$\underline{\text { ABSTRACT }}$
The recent crisis highlighted the importance of globally active banks in linking markets. One channel for this linkage is through how these banks manage liquidity across their entire banking organization. We document that funds regularly flow between parent banks and their affiliates in diverse foreign markets. We use the Great Recession as an opportunity to identify the balance sheet shocks to parent banks in the United States, and then explore which foreign affiliate features are associated with those businesses being protected, for example their status as important locations in sourcing funding or as destinations for foreign investment activity. We show that distance from the parent organization lays a significant role in this allocation, where distance is bank-affiliate specific and depends on the ex ante relative importance of such locations as local funding pools and in their overall foreign investment strategies. These flows are a form of global interdependence previously unexplored in the literature on international shock transmission.
\end{abstract}

Nicola Cetorelli

Federal Reserve Bank of New York

33 Liberty Street

New York, NY 10045

nicola.cetorelli@ny.frb.org

Linda S. Goldberg

Research Department, 3rd Floor

Federal Reserve Bank-New York

33 Liberty Street

New York, NY 10045

and NBER

linda.goldberg@ny.frb.org 


\section{Introduction}

The Great Recession clearly focused attention on the importance and international interconnectedness of global banks. Individual banks experienced unprecedented balance sheet disruptions, and pursued various strategies for dealing with these shocks. Those banks with networks of foreign affiliates had, as one potential margin of adjustment, a possibility of reallocating liquidity across the organization. We explore this pattern of activation of "internal capital markets” within global banks using detailed, and so far unexplored, confidential regulatory data on all U.S. banks with foreign branches and subsidiaries. Using methodological advances along the lines of Khwaja and Mian (2008) and bank-specific shocks to parent bank balance sheets as in Acharya and Schnabl (2010), we show that reallocations of internal liquidity are not evenly spread across all foreign affiliates when a parent bank is hit with a funding shock. International transmission is, on some level, a bank-specific phenomenon influenced by its prioritization of operations in terms of a range of “core” and "periphery” considerations.

Despite the potential importance of this form of international capital flows, there is very little direct evidence or analysis of how such internal capital market transfers work within banking organizations. The first direct evidence, provided in Cetorelli and Goldberg (forthcoming), used bank-specific data and demonstrated that these flows transmit policyinduced liquidity changes across markets even during "normal” times. As a result, these banks exhibit behaviors that can impinge on the effectiveness of monetary policy, impairing the bank lending channel at home. Related work, Cetorelli and Goldberg (2011), uses data aggregated over banks for a range of individual industrialized countries. During the Great Recession, bank balance sheet shocks were transmitted to emerging markets through a range of channels: cross border flows, lending by affiliates in the foreign markets in which they operate, and those unaffiliated banks in foreign markets that rely on interbank market funding channels.

To some degree, such evidence provides fuel for concerns of many smaller countries that foreign banks might restrict participation in local markets during a crisis, draining funds that otherwise would be available for local businesses. Larger countries also expressed concerns that their banks might go abroad and target the needs of affiliates in other markets, exasperating conditions at home. Indeed, during the Great Recession there was an initial surge in the outflows of funds from many foreign-owned bank branches in the United States to their affiliate organizations outside of U.S. borders. In part to avoid sharp contractions in U.S. and 
international business activity, various emergency lending facilities in the United States provided extensive dollar liquidity to foreign banking organizations, also serving to stabilize activity in the United States. ${ }^{1}$

There also were significant changes in the flows between U.S. owned banks and their affiliates abroad. In the very early stages of the crisis, the foreign affiliates of U.S. owned banks also became, in aggregate, net recipients of funds from their parents, as shown in Figure 1. After the Lehman failure and during the peak of the crisis, and again later in 2009, the foreign affiliates were conduits for inflows of funds back to their parent organizations in the United States. This directional inflow into the United States through internal capital markets for this same group of banks was reversed in 2010, when foreign affiliates relied much more extensively on borrowing from their banking organizations compared with what previously had been the case. It also is noteworthy that regional patterns of aggregate changes differed sharply from the aggregate story, and banks also differed from each other in their allocation patterns.

None of the prior studies have explored the features of countries and banks that make the branches or subsidiaries more likely to be buffeted by or protected from changes induced by shocks to parent bank balance sheets. In this paper we econometrically conduct this type of assessment, thus getting into the "decision rule" governing the operations of global banks and their overall management of funding and investment strategies. Such analysis would significantly advance our understanding of international banking and more broadly of the channels of transmissions in a financially integrated world. It also provides important insights into the normative discussion on rules and regulations affecting global banking and international capital movements. We use bank-specific data from confidential regulatory reports filed by all U.S. global banks that allow the complete mapping, by bank, of cross-border investments and of local investment and funding, and the tracing of internal capital flows between parent banks and their affiliates across the globe. To our knowledge, this data has never been explored for research

\footnotetext{
${ }^{1}$ See blog discussion on this topic by Linda Goldberg and David Skeie "Why did US Branches of foreign banks borrow at the discount window during the crisis? http://libertystreeteconomics.newyorkfed.org/2011/04/why-did-usbranches-of-foreign-banks-borrow-at-the-discount-window-during-the-crisis.html on the Term Auction Facility (TAF), see Olivier Armantier, Sandy Krieger, and Jamie McAndrews. 2008. On the central bank dollar swap facilities, see Linda Goldberg, Craig Kennedy, and Jason Miu. 2011. One factor in the need for funding in foreign markets during the crisis was the prior build-up of maturity and currency mismatches within and across currencies on the balance sheets of banks (BIS CGFS March 2010).
} 
purposes. ${ }^{2}$ Given the bank-specific balance sheet shocks at the onset of the Great Recession and the claim that their impact is related to asset-backed commercial paper (ABCP) exposure, we examine which features of parent banks and foreign affiliates were associated with greater adjustments in internal flows within the global banking organizations. We demonstrate that bank business models and country and institutional features play clear roles in international transmission and contagion through internal capital markets of banks. Some foreign markets are, for particular parent banks, “core investment markets” that remain as destinations for funding. Other foreign locations serve as "core funding markets" that would send even larger net flows to parent banks in times of parent balance sheet disturbances. In general, a range of policy and institutional "distance" measures also influence the magnitudes of these flows. This channel is shown to be economically important to both the parent banks and the foreign markets in which their affiliates are located.

This research directly relates to three rich literatures. First, the literature on international transmission and contagion during crisis events, as in Forbes and Rigobon (2002) and Edwards (2002), concentrates on refining the concept of contagion, or, as in Forbes and Chinn (2004), addresses whether this arises through international trade linkages, exposure to common competitors in trade, reliance on the international interbank market, or through foreign direct investment. Using data on stock and bond market returns, this work found that from the late 1990s bilateral bank lending between countries became a sometimes significant determinant of international linkages, although this channel was still dominated by direct trade linkages. ${ }^{3}$ For the recent crisis, (Acharya and Schnabl 2010) show that the use of asset-backed commercial paper (ABCP) conduits by banks led the crisis transmission around the globe.

Second, we deepen an understanding of the role of banks in international transmission, building on insights from early studies by Peek and Rosengren (1997, 2000) and van Rijckeghem and Weder (2003). In line with some of these papers, theoretical work by Devereux and Yetman (2010) argues that the recent crisis differs from earlier contagion episodes in that transmission recently was through the balance sheet constraints on global banks. De Haas and Lleyveld (2010), Popov and Udell (2010), Puri, Rocholl, and Steffen (2010), Cetorelli and Goldberg

${ }^{2}$ Goldberg (2002) and Cetorelli and Goldberg (2006) use this data to describe bank international exposures and related risks.

${ }^{3}$ A related literature addresses the sources of business cycle co-movement. Imbs (2004) finds stronger business cycle linkages between countries with larger financial ties. Prasad et al. (2007) surveys an extensive literature that explores the role of global financial linkages in economic volatility. 
(2011) and Buch, Koch, and Kotter (2011) demonstrate that international retail and syndicated lending reflected stresses on parent banks during the global financial crisis.

Third, we add to an evolving literature on internal capital markets. Conceptually, internal capital market flows are viewed as leading to a more efficient allocation of resources (see Stein (1997), Gertner, Scharfstein, and Stein (1994), and Stein (2002)), or as a managerial tool to mediate agency frictions within a firm, across separate divisions, (e.g., Rajan, Servaes, and Zingales (2000), Scharfstein and Stein (2000)). ${ }^{4}$ Cetorelli and Goldberg (forthcoming) provided the first direct evidence in the context of banks and monetary policy transmission across countries. That work complements other studies that provided indirect tests of internal capital markets in domestic or global banking organizations, such as de Haas and Lleyveld (2010), Cetorelli and Goldberg (2011). ${ }^{5}$

Overall, the present paper provides direct evidence of patterns of liquidity management in global banking organizations. In particular, we present an econometric evaluation of the features of parent banks and overseas affiliates that influence the allocation of organizational liquidity. The results, that there are features that define "core" and "periphery" business functions, are clearly important for understanding potentials for international contagion through banks. We conclude that the insights are valuable for properly constructing liquidity and lender-of-lastresort responses by official agencies in the event of market disruption.

\section{U.S. banks and their foreign affiliates}

Banks can engage in international activities in many ways. Historically, banks from developed economies were involved in cross-border lending to sovereign borrowers, and later to private bank and non-bank counterparties. Over time, a broader array of financial services also was offered to overseas clientele. In some cases, the parent bank would set up a branch office in a

\footnotetext{
${ }^{4}$ Another relevant literature argues that countries that are more remote suffer from more international financial volatility, as in Rose and Spiegel (2009).

${ }^{5}$ That banks - as other business organizations - have active internal capital markets is not new, and evidence has been reported, among others and large for banks in the United States, in Houston, James and Marcus (1997), Campello (2002), Ashcraft (2006, 2008), and Ashcraft and Campello (2007). Recent contributions are by Schnabl 2009 and Khwaja and Mian 2008. This focus on internal capital markets of global banks is complementary to analysis of the entry decisions of foreign banks into specific destination markets (Claessens and van Horen 2008; Cerutti, Dell'Ariccia, and Martinez Peria 2007; Buch 2005). Much of that literature considers linkages between industrialized with emerging markets with most emphasis on lending activity. Our treatment subsumes these markets, but also considers the results of entry into markets where affiliates may draw funding, such as is the case in many industrialized countries.
} 
particular location in order to better serve those markets and interact with customers. Alternatively, banks could set up foreign subsidiaries, which are separate legal entities. Many factors influence this choice, including taxes, regulatory restrictions on entry and branching, preferences for retail operations, and economic and political risks. ${ }^{6}$ Substantively, this choice has implications for the location of banking regulation, with home country supervisors having primary responsibility for bank branches and host country supervisors having responsibility for subsidiaries. The choice also matters for the degree to which liquidity can flow unimpeded within the banking organization. To a first approximation, intra-bank transactions are restricted to a small share of the balance sheet for subsidiaries, but are closer to unrestricted between parent banks and their overseas branches. ${ }^{7}$

From the perspective of the United States, the total number of globally active banks has declined considerably over time, from nearly 200 in the late 1980s to closer to 75 in the early 2000s. ${ }^{8}$ This trend broadly reflected the widely documented pattern of industry consolidation that occurred over the same time period. These banks can be exclusively engaged in cross-border transactions, or could have a combination of activities that includes having local affiliates in foreign markets. For our analysis, we begin with the full sample of internationally active United States banks, which are those institutions that file the Federal Financial Institutions Examinations Council (FFIEC) Country Exposure Report (FFIEC 009). ${ }^{9}$ In this quarterly filing, each bank itemizes their claims, assets, and liabilities by foreign country. The FFIEC 009 report is strictly confidential and therefore micro details cannot be made public. However, with its information, by bank and by foreign country, on intra-organization borrowing and lending, it is precisely the type of data needed to further our understanding of liquidity management strategies of globally active banks. To the best of our knowledge this dataset has never been used before for such research purposes.

\footnotetext{
${ }^{6}$ Cerutti, Dell'Ariccia, and Martinez Peria (2007) provided econometric analysis of such choices for entry into Latin America and Eastern Europe. From the vantage point of countries choosing an optimal structure of foreign entry in their own markets, Fiechter et al. (2011) argues that there is no one-size-fits-all conclusion.

${ }^{7}$ Within the United States, regulatory restrictions are provided in Sections 23A and 23B of the Federal Reserve Act.

${ }^{8}$ Goldberg (2006) and Cetorelli and Goldberg (2006) provide a broader description of this evolution over the last 20 years.

${ }^{9}$ This report must be filed by every U.S. chartered, insured, commercial bank in the United States, including the District of Columbia, Puerto Rico, and US territories and possessions, or it's holding company, provided that the bank (or holding company) has, on a fully consolidated bank basis, total outstanding claims on residents of foreign countries exceeding \$30 million in aggregate. The reporters can be U.S. owned banks or foreign bank subsidiaries in the United States.
} 
Since our analytical focus is on liquidity management across the global internal capital markets and their role in international transmission of shocks, we apply screens to the full dataset to restrict the sample of banks to those that actually have foreign affiliates. Our screens for this purpose are, by bank and by foreign location, for the existence of either positive "local liabilities" in foreign countries or affiliate support by the parent. ${ }^{10}$ Starting with 2006Q1 and continuing through 2010Q1, this set of screens reduces the number of banks in our sample to more than 50 over the full interval, although closer to 42 at any single date (Table 1). As the table shows, this group of banks is split between U.S.-owned and those with foreign parent organizations.

Given this unique data source, we are able to consider the details of this global presence by banks. The data show that many of these banks maintain overseas affiliate(s) in offshore financial centers. ${ }^{11}$ Also, many foreign-owned banks have an affiliate in their parent country. In every quarter, at least 30 banks have affiliates in at least two foreign countries. ${ }^{12}$ Across all banks, the foreign affiliates are broadly dispersed around the globe and span a total of 121 countries.

Visualizations of the geographic distribution of the foreign affiliates of U.S. banks ${ }^{13}$ are provided in Figures 1 and 2. Figure 2 shows counts of how many U.S. banks had affiliates in any foreign country at 2007Q2 (the raw data is in Appendix Table 1). Figure 3 shows the relative dollar value of total U.S. bank positions in these countries, with the value capturing the sum of the total of local liabilities (in both local and foreign currency) and net inflows from the parent organization (without adjustment if there are net outflows). ${ }^{14}$ A large number of U.S. banks have affiliates in Canada, Hong Kong, Ireland, Taiwan, and the United Kingdom, in addition to the Cayman Islands. However, a large number of countries, fully half of the sample,

\footnotetext{
${ }^{10}$ The existence of local lending in a country is a sufficient condition for a foreign affiliate, but is not used as a screen since not all affiliate offices engage in lending activity. We include the country-affiliate pair if local liabilities, such as derived from accepting local deposits, or net due flows are observed in any of the observations periods of all sample.

${ }^{11}$ According to the International Monetary Fund, there are 46 countries that meet the definition of offshore financial center. See Zerome (2007) for a discussion of alternative approaches to identifying OFCs.

${ }^{12}$ Note: for the purpose of this table and the econometric analysis which follows, we exclude the large institutions that became banks or had a change in entity status late in 2008Q4 and in 2009Q1/Q2. Examples of such excluded banks are Goldman, Morgan, GMAC, CIT, and American Express.

${ }^{13}$ By "U.S. banks" we are referring to all legal entities in the United States as indicated in Table 1, regardless of whether these are U.S. owned or foreign owned.

${ }^{14}$ We do not address the issue of determinants of bank entry in specific foreign markets. As shown by Claessens and Van Horen (2008), foreign entry tends to be associated with common language, similar legal systems and banking regulations, and geographic proximity. These are measures of physical and institutional distance that are sometimes related to information costs.
} 
have affiliates of only two or three U.S. banks operating in the local markets. There is a wide variance in the total value of the U.S. bank liabilities across all of these countries. The median country in our sample had about $\$ 5$ billion in U.S. bank liabilities, while the largest countries had over $\$ 100$ billion, and liabilities in the United Kingdom were even an order of magnitude larger.

What are some of the characteristics of these global banks? Drawing on a broader set of regulatory reports filed by individual banks or bank holding companies, e.g. the Federal Financial Institutions Examinations Council (FFIEC) 031 "Call Report” and the Y9-C, ${ }^{15}$ we collect parent bank information, including information pertaining to their size (total assets), solvency and liquidity, and foreign lending. Foreign lending is conducted through cross-border flows and through local claims, which are extended by a bank's affiliated offices outside its borders. The upper panel of Table 2 presents summary statistics for the U.S. banks, with the average 2006Q1-2007Q2 data taken as a pre-crisis reference point, and comparable statistics for 2009Q2 and 2010Q2 to reflect post-crisis evolution.

The median global bank starts out as moderately sized, at over \$50 billion in assets. However, the size distribution is very broad across all banks. The mean asset size is about $\$ 200$ billion, reflecting the presence of some very large banks in the sample. Across all the banks, liquid asset shares are typically under 3 percent of total assets, although some banks had liquidity over 5 percent prior to the onset of the Great Recession. Bank equity or solvency ratios were generally close to 9 to 10 percent of bank total assets. For the banks in our sample, foreign “external” lending typically ranges from 2.5 to 5 percent of total bank assets. International intrabank flows are captured by reporting of "total net due from," which is total internal lending (if positive) or borrowing (if negative) of the bank with its full spectrum of their foreign affiliates. A gross metric ${ }^{16}$ indicates that the pre-crisis internal capital market balances were typically in the range of 2 to 8 percent of assets. Some parent banks were net lenders to their foreign affiliates, while others were net borrowers.

15 Through the FFIEC 031 report, we used the following variables: total assets (RCFD2170), total loans (RCFD2122), total foreign loans (RCFN2122), equity (RCFD3210), and liquid assets constructed as the sum of securities, trading assets, and (RCFD1754+RCFD3545+RCFD1350). From the FFIEC 009, we have for the bank (or holding company), on a fully consolidated bank basis, the following variables: total cross border claims constructed as the sum of cross border claims by banks, public, and other (C915+C916+C917), total foreign office claims on local residents in non-local and local currency constructed as the sum of foreign office claims by banks, public, and other, and foreign office claims in local currency (C918+C919+C920+C922), net due to (or due from) own related offices in other countries (8595), and foreign office liabilities constructed as the sum of foreign office liabilities in non-local currency and in local currency (C938+C939).

${ }^{16}$ The absolute value of net due in relation to total bank assets. 
An even starker illustration of the absolute scale of internal capital flows of these banks is provide in Figure 3, which shows gross intra-bank flows ${ }^{17}$ on the same axes as gross interbank flows. These flows are of a similar order of magnitude. Similar observation on scale can be made on the basis of Treasury International Capital System data, which show that over half of total U.S. bank claims and liabilities internationally are vis-à-vis their own affiliates. ${ }^{18}$

As the crisis progressed and then abated, some of the balance sheet characteristics of these banks evolved substantially. The contraction in the foreign loan share is noteworthy, an observation consistent with a more inward focus on lending. ${ }^{19}$ Also, the use of internal capital markets by banks changed. Some banks reduced reliance on this channel, while others expanded intra-bank flows. Figure 4 shows the totals across banks on net related borrowing over the full time frame of the crisis.

The lower panel of Table 2 provides details for the foreign affiliates of the U.S. reporting banks, with each "affiliate" observation really an amalgam of all affiliates of a given bank within a given foreign country. The information presented emphasizes dimensions along which each affiliate market might be assessed as "core" or "periphery" from the vantage point of the parent organization. Two types of information are highlighted: the financing of the affiliates, and their relative importance in the total foreign lending of the parent. These respectively are viewed as indicative of the degree to which a specific affiliate market, from the vantage point of a parent bank, is a core or periphery location from the vantage point of sourcing "funding" or directing resources for "investment" or lending activity. ${ }^{20}$ In terms of funding, we are interested in whether local deposits from a particular affiliate are large relative to the range of deposits accepted internationally. For investment strategy, we examine alternative variables include lending defined as a) that exclusively done by the affiliates, b) the sum of cross border and local lending to a particular foreign market, or c) the long maturity share for a particular economy. We posit that the

\footnotetext{
${ }^{17}$ Absolute values of net due to and net due from US banks with all affiliates as reported in FFIEC009

${ }^{18}$ Thanks to Gian Maria Milesi Ferretti for the relevant computations based on TIC bank claims and liabilities. These data are not exactly comparable to our underlying data. The bank flows that are captured are vis-à-vis all affiliates, not purely bank affiliates in foreign markets.

${ }^{19}$ Rose and Wieladek (2011) argue that inward reorientation by British banks amounted to financial protectionism.

${ }^{20}$ The data used for this analysis is collected by bank and by affiliate country, capturing, for each country in which the reporter has an office or offices, the net liabilities (or claims) of that office or those offices on all other offices of the respondent that are located in other countries. If the offices in a given country taken together have a net "due to" position with all related offices in all other countries combined, a positive figure should be reported and indicates that the affiliate is borrowing from the rest of the banking organization; a net "due from" position should be indicated by a negative sign and indicates that the affiliate is lending to the rest of the banking organization. http://www.ffiec.gov/PDF/FFIEC_forms/FFIEC009_201103_i.pdf Schedule 1.a memorandum item reporting.
} 
larger the affiliate share in the total funding and lending activity of a given bank, the greater the chance that this is a protected or core affiliate. The commitment may be even more secure if a larger share of loans is of longer maturity. Finally, we allow for the possibility that significant differences in claims flows may arise when claims are measured on an immediate counterparty basis versus adjusted for outward risk in the event there is an external guarantor of some claims.

The lower panel of Table 2 shows that there are approximately 550 bank-affiliate market observations at any point in our sample. ${ }^{21}$ There is a bi-modal distribution of affiliates per bank. Some banks have affiliates only in one or two foreign countries; many other U.S. global banks have affiliates in over twenty countries, with some in excess of 50 countries. The funding models of banks also appear bi-modal. For some bank affiliates about 75 percent of financing is raised locally. In others, almost no local funding is collected. There also is a broad distribution of importance across affiliate markets to the overall international lending activity of each parent bank. Indeed, one interesting observation is that about 40 percent of bank-affiliate locations had no local lending. Funds collected domestically apparently are used for other purposes or flow to counterparties outside of the local markets. An interesting implication is that, while internal capital market flows may spillover to local market lending by some bank affiliates, this need not be the case. Such observations provide a useful nuance to the literature on bank lending channel effects from internal capital market transfers. The type of evidence we present here shows that such transmission will likely not occur uniformly from all foreign banks within specific affiliate locations. ${ }^{22}$

\section{Econometric Analysis of Transmission through Internal Capital Markets}

We now turn to the internal capital market flows across bank affiliates in response to the specific shocks hitting parent banks in the recent crisis. Our dependent variable will be the change in internal capital market borrowing (or lending) of an affiliate in a foreign location with

\footnotetext{
${ }^{21}$ The units of observation are allocations across by-country affiliates by individual banks, instead of at the level of individual foreign branches or subsidiaries which we do not directly observe.

${ }^{22}$ Looking at a range of home countries and a range of host markets, Cetorelli and Goldberg (2011) provided indirect evidence that shocks to parent banks were transmitted to emerging markets through cross-border lending and that there was a smaller contraction in lending done directly by the affiliates. Kamil and Rai (2010) confirm this pattern for Latin American countries, and also show that the local lending activities by the foreign banks - especially when heavily funded by local deposits instead of parent bank's resources or wholesale markets - reduced the amount of contagion from the international liquidity squeeze. Claessens, Dell'Ariccia, Igan and Laeven (2010) provide cross-country evidence on the spreading of the crisis into macroeconomic and financial performance metrics, also finding that bank dependency on wholesale funding markets played a significant role in amplification.
} 
the rest of the parent banking organization. The unit of observation is dimensioned by bank, country, and time. The econometric methodology recognizes that these flows could be influenced by features of countries in which affiliates are established, features of parent banks, and features that are specific to affiliate locations by bank.

Among country characteristics, we consider the importance of distance from the U.S. parent - in geography, institutions and policy, the degree of capital account openness of each location, the prevalent exchange rate regime, and affiliate market status as an offshore financial center. $^{23}$ Among parent bank characteristics, we focus on size, solvency, liquidity, and investment diversification among foreign locations. Our initial OLS specifications include the country and bank-level characteristics, thereby adding a first extra dimension of insights to the international transmission literature.

Yet, establishing the causes of transfers, whether due to a shock to the parent bank's balance sheet or a shock to the foreign market in which the affiliate resides, requires separating potential contamination of each by concomitant changes in the other. This identification issue is long recognized in the literature on international contagion as difficult to address, as summarized by Rose and Spiegel (2010) and earlier addressed by Forbes and Rigobon (2002).

The multiple dimensionality of the dataset allows us to raise the bar in handling this problem. We adopt a difference-in-difference identification strategy similar to that employed in Khwaja and Mian (2008) and Cetorelli and Goldberg (2011). This approach relies on two points: 1) the initial liquidity shock is not felt homogeneously across the individual parent banks that have foreign affiliates, and 2) more than one parent bank has affiliates in a particular foreign location. On the first point, and following Acharya, Schnabl and Suarez (2009), Acharya and Schnabl (2010) and Kacperczyk and Schnabl (2010), we posit that the initial shock that hit banks in the United States was proportional to their ex ante reliance on ABCP conduits. Later, we assume that some of this balance sheet pressure was reversed by the range of liquidity facilities introduced after the Lehman bankruptcy. On the second point, we obtain identification by observing the differential response by the affiliates of separate parent banks in a given country, thus allowing us to control for common factors affecting market conditions in a particular foreign

\footnotetext{
${ }^{23}$ While the legal form of the affiliate -- as a branch or a subsidiary-- could matter for effective activation of the internal capital market channel, data do not identify the mix of branches or subsidiaries in any affiliate location. Moreover, the decision on branch or subsidiary form is likely determined by similar sets of country characteristics included as controls in our regressions.
} 
location. By applying this difference-in-difference approach we isolate the role of bank-specific business models versus affiliate market effects in international transmission through internal capital markets. We provide a range of OLS results and also conduct fixed effects specifications, along with robustness checks.

We use this approach to explore our two key conjectures that transmission through internal capital markets depends on how each bank classifies each affiliate location as "core" versus "periphery" according to: 1) affiliate funding strategies and, 2) importance as an "investment" market in the parent bank's "portfolio". On the first point, regarding finding strategies, (parent) banks differ from one another in their reliance on local liabilities to fund local investments. Moreover, each bank individually follows heterogeneous strategies in local funding reliance across their own foreign affiliate locations. ${ }^{24}$ The econometric analysis exploits both these inter- and intra-bank heterogeneities in funding strategies, and we conjecture that in the event of a shock to the parent, internal funds are more likely to be drawn from affiliate locations that are more reliant on local funding pools. On the second point, we exploit the fact that banks differ in their global investment strategies as reflected by the amounts of lending extended in each foreign location. Heterogeneity across banks along this second dimension captures, among other things, differential strategies of business expansion and market penetration. Heterogeneity within banks instead captures the relative importance for each bank of its investments in a particular market. We conjecture that, in response to a shock to the parent, funds are drawn more intensely from "distant" or "periphery" investment locations - those representing a smaller share of total foreign claims - than from "core" locations.

Overall, by focusing on these two specific dimensions of global banks' business model, we go beyond the observation of internal capital markets in aggregate, between parent and its foreign affiliates as a whole, and we are able instead to track the direction and the intensity of internal borrowing and lending in and out of each global bank's own entire set of foreign locations. Thus, we provide direct evidence on a specific channel of international transmission by banks, nuanced by the international expansion and funding strategies of those same banks. Through this evidence we add to the understanding of contagion and transmission that have been explored in more "macroeconomic" studies.

\footnotetext{
${ }^{24}$ In the context of this paper, local always refers to the location of the foreign affiliates of a U.S. parent bank. Hence, local is synonym with foreign country.
} 


\section{III.1 The econometric methodology}

The basic supply schedule for bank $i$ internal lending with its' affiliates in country $j$ at time $t, L_{i j}$, is expressed in terms of (log) changes from before to after the shock as

$$
\Delta L_{i j}=\beta_{0}+\beta_{1} \cdot \Delta D_{i}+\eta_{j}+\varepsilon_{i j}
$$

$\beta_{0}$ is a constant term, $\Delta D_{i}$ is the indicator of the funding shock sustained by parent bank $i$, and $\eta_{j}$ is an unobservable term capturing simultaneous market shocks to affiliates of all banks in located in country $j$. The term $\Delta L_{i j}$ captures the change in internal lending from before to after the event, and banks that were hit more by an adverse liquidity shock should be those that rely more on changes in internal lending with affiliates.

In this particular estimating framework, as shown by Khwaja and Mian (2008), basic OLS could generate biased estimates of the internal capital market supply effect $\hat{\beta}_{1}$ if there is a correlation of supply with any simultaneous liquidity demand shocks embedded in the unobservable term $\eta_{j}$. Country fixed effects on model specification (1) can absorb any liquidity demand driven contamination thus resolving the bias problem affecting the OLS estimation. The resulting model specification is

$$
\Delta L_{i j}=\gamma_{1} \cdot \Delta D_{i}+\gamma_{j} \cdot F E_{j}+\varepsilon_{i j}
$$

with $\gamma_{1}$ now unbiased and $\gamma_{j}$ being a vector of country fixed effect coefficients. In essence, this alternative model specification achieves identification by comparing the impact on internal lending of separate banks $i$ to their own affiliates in the same country $j$. Any common shock to funding demand factors in country $j$ would be absorbed by its own country indicator variable, thus leaving the coefficient $\gamma_{1}$ as an unbiased estimator of changes affecting the net supply of funding of each parent.

This basic methodology can be refined in a number of directions. As said earlier, our dataset allows us to push further the identification strategy, having for the first time an in-depth look at from where exactly global banks may be may be drawing funds and to which location they may be directing funds in times of positive or negative shocks. As noted, we are particularly interested in testing whether these flows are related to the importance of local funding pools and 
“investment" locations, with potential different consequences for respective core and periphery locations for each global bank.

While the fixed effects specification improves on OLS by facilitating identification of internal capital supply versus demand, it may be that both country and parent bank characteristics can be important determinants of specific internal funding dynamics. We expand on the basic methodology by allowing the parameter $\beta_{1}$ to incorporate $i$ and $j$ features that may contribute to international transmission. Hence, we conduct the empirical exercise using the broader model specification

$$
\Delta L_{i j}=\beta_{0}+\eta_{i}+\delta_{j}+\beta_{1} \cdot \Delta D_{i}+\varepsilon_{i j}
$$

where $\beta_{1}$ to broadly defined as

$$
\beta_{1}=\beta_{0}+\bar{\beta}_{i} \bar{X}_{i}+\bar{\beta}_{j} \bar{X}_{j}+\bar{\beta}_{i j} \bar{X}_{i j}
$$

and vectors of characteristics of parent banks $\left(\bar{X}_{i}\right)$, affiliate countries $\left(\bar{X}_{j}\right)$, and affiliate bank pairs $\left(\bar{X}_{i j}\right)$ can be introduced.

\section{III.2. Identifying the funding shock timing and incidence}

As it has been widely described, the initial stage of the financial crisis materialized in the second half of 2007 in the form of a broad shortage of U.S. dollar funding. Banks and other financial institutions, both in the U.S. and abroad, had been accumulating substantial dollar denominated assets, mainly long-term securities derived from real estate activity and had funded such positions mainly through short-term dollar liabilities. The asset-backed commercial paper (ABCP) market had been a crucial component in such dollar funding activities. ${ }^{25}$ Commercial paper had grown to be the largest instrument in total U.S. short-term funding, with the ABCP component representing the lion share. While ABCP is issued by entities (conduits) distinct from the financial institutions in our sample, those entities can operate with the direct backing of such institutions, through the existence of liquidity or credit enhancements. Large commercial banks, both U.S. and foreign (mainly European) were among the largest providers of such enhancements.

${ }^{25}$ Details are provided in Acharya and Schnabl (2010), Acharya, Schnabl and Suarez (2009), and Kacperczyk and Schnabl (2010). 
Many ABCP entities were unable to continue issuing new paper in the second half of 2007, once investors became concerned about the overall quality of the assets backing commercial paper issuance. As argued in Acharya, Schnabl and Suarez (2009), off-balance sheet commitments by banks resulted in their massive absorptions of the assets of the conduits they sponsored. Consequently, the ex-ante large off-balance sheet exposures to the ABCP market materialized as a severe funding shock on many banks' balance sheet, and many of these banks experienced larger drops in stock prices in subsequent months. We use their data as a measure of individual banks' pre-crisis exposure to ABCP (January 2007). ${ }^{26}$ This ex-ante indicator is used in our basic model specification to proxy the degree of parent bank balance sheet disruption $\Delta D_{i}$.

We examine two "shock" dates. For the purpose of our analysis, we take the pre-crisis period as beginning in 2006Q1 and continuing to 2007Q2. Indeed, short-term dollar funding markets exhibited no sign of turmoil throughout the end of July and early August as shown in Figure 4. We then define the period 2007Q3 to 2007Q4 as a "first shock" period, as the dollar funding pressure resulting from the events described above became more acute. We conjecture that the global banks that had been more highly exposed in the ABCP market would face larger funding imbalances. These same banks would therefore have larger needs to activate internal borrowing and lending with their foreign affiliates. Thus, for each bank-affiliate observation we construct the initial $\Delta L_{i j}$ as the pre-crisis average borrowing of affiliates in each foreign location from the rest of the banking organization (over the 2006Q1-2007Q2 period) and the average over 2007Q3 and 2007Q4.

We end the first shock period at 2007Q4 to coincide with the subsequent Federal Reserve institution of the Term Auction Facility in late December 2007, which provided emergency funding to banking institutions. This intervention was unprecedented and large in size. Hence, we define the period 2008Q1 through 2008Q2 as a "second shock" period. We treat this policy intervention event as a positive liquidity shock on parent banks' balance sheet. We then look for any subsequent change in behavior by the same sets of banks, as differentiated according to their

\footnotetext{
${ }^{26}$ We thank Viral Acharya and Philipp Schnabl for sharing this data. The conduit group comes from Moody's Investor Service reports. Acharya and Schnabl match conduits to sponsoring organizations and then match the sponsor to the consolidated financial company. We match these consolidated financial companies to the U.S filers of regulatory report FFIEC 009. If there are U.S. filers without Moody's rated conduits, we treat the ABCP value as zero. For each filer, the conduit value is scaled relative to 2007Q2 bank equity.
} 
same pre-crisis ABCP exposure. The second $\Delta$ for estimation defines the "pre" period as 2007Q3-2007Q4 and compares this interval with data averages over the first half of $2008 .^{27}$

We purposefully end our empirical exercise before the events associated with the failure of Lehman in September 2008. First, our identification strategy relies upon banks’ pre-crisis exposure to the ABCP market. Observing behavior based on balance sheet characteristics more than twelve months apart would probably introduce noise that would be hard to control. Second, the Lehman event effectively marks a separate stage of the crisis, both in magnitude and pervasive repercussions across the globe, that would probably require a separate study altogether. The earlier events clearly provide cleaner econometric opportunities to explore the liquidity management of global banks and their roles in international transmission, which are the central subjects of this study.

\section{$\underline{\text { III.3 Regression variables }}$}

The dependent variable in the regressions is the change in the borrowing by the foreign affiliates of bank $i$ in location $j$ from the rest of the banking organization (change in "net due") over the time periods indicated above. A positive value reflects either an increase in borrowing by those affiliates or a reduction in affiliate lending to the rest of the banking organization. The bank-specific ex ante exposure to dollar funding shocks is assumed proportional to Exposure , $_{\text {, }}$ the bank's ratio of ABCP to its equity in early 2007.

There are a set of country specific and parent bank specific variables that enter the specifications. We expect that affiliates in countries more distant from the United States along a range of dimensions will tend to have a larger response of internal capital markets in the event of a shock to the parent organization. For this purpose, distance might reduce the commitment of

\footnotetext{
${ }^{27}$ The facilities fall under the heading of liquidity facilities versus lending facilities. The more traditional provision of short-term liquidity to banks and other depository institutions occurred through the traditional discount window, the Term Auction Facility and through the bilateral currency swap agreements approved and in some cases later expanded with 14 foreign central banks. The Federal Reserve's Section 12(3) Lending Families were introduced in two waves, First, in March 2008 the Term Securities Lending Facility (TSLF) and Primary Dealer Credit Facility (PDCF) were introduced. In the Period from September through November 2009, the Asset-Backed Commercial Paper Money Market Mutual Fund Liquidity Facility (AMLF), Commercial Paper Funding Facility (CPFF), Money Market Fund Liquidity Facility (MMIFF), and Term Asset-Backed Securities Loan Facility (TALF) were introduced. See "The Federal Reserve's Section 13(3) Lending Facilities to Support Overall Market Liquidity: Function, Status, and Risk Management, Office of Inspector General (November 2010). http://www.federalreserve.gov/oig/files/FRS_Lending_Facilities_Report_final-proof_Nov16_10.pdf.
} 
the parent organization to a stable net supply of funds to the affiliate and leads to larger changes in net due flows. Our metrics for distance are:

- Physical distance ( Ldistnyc $_{j}$ ). ( $\left.\log \right)$ physical distance is the great circle distance of the affiliate country from New York City, from Rose and Spiegel (2009). ${ }^{28}$

- Institutional Distance ( Polity $_{j}$ ). Under the assumption that institutional comparisons with the United States provide a metric of effective distance, we use a scalar ratings variable that ranges from strongly democratic $(+10)$ to strongly autocratic $(-10){ }^{29}$

- Monetary policy distance ( Exrate $_{j}$ ). For monetary policy distance, we consider whether the country has a de facto exchange rate peg with the U.S. dollar. If there is no peg to the dollar, the monetary policy distance is assumed larger. We start with the coarse metrics in Ilzetski, Reinhart and Rogoff (2009, 2011), in which a country with a de facto peg or crawling peg has a rating 1 or 2, plus we include whether the central currency of the peg as the U.S. dollar. For countries missing from that classification, we take observed recent exchange rate movements for comparable guidance. Exrate $_{j}=1$ if a de facto dollar peg or crawl, 0 otherwise.

- Financial frictions $\left(\right.$ KAopen $\left._{j}\right)$. Bank internal capital market flows may be managed differently for countries with stricter capital controls in place. To capture the extent of this financial friction we use the Chinn and Ito (2008) capital control measure. ${ }^{30}$

- Offshore financial center status $\left(O F C_{j}\right)$. We use the International Monetary Fund definition of offshore financial centers which encompasses locations that primarily orient business toward non-residents, have favorable regulatory environments andlow or zero taxation schemes, are disproportion in size of financial sector and domestic financing needs, and primarily deals in non-local currencies and entrepot business (Zerome 2007, Table 1).

\footnotetext{
${ }^{28}$ http://faculty.haas.berkeley.edu/arose/MIMIC2.pdf

29 Produced by the Center for Systemic Peace, Polity IV Project. The data source and related discussion of construction are available at: http://www.systemicpeace.org/inscr/inscr.htm and http://www.systemicpeace.org/inscr/p4manualv2009.pdf

${ }^{30}$ For some offshore financial centers with missing Chinn-Ito observations, and after discussions we Chinn and Ito, we assign high values of openness to these countries.
} 
Parent bank characteristics also can influence the use of internal capital markets in response to a balance sheet shock. Activation of this channel given an adverse shock can potentially be larger for parent banks that ex ante have weaker liquidity positions, lower solvency values, less focus on foreign markets in lending, more focus on using foreign affiliates as funding sources, and more geographically diversified foreign affiliates. All parent bank metrics are constructed using data as of 2007Q2, which we take as the end of the pre-crisis period. These variables are defined as:

- $\quad$ Size $\left(\right.$ Totalassets $_{i}$ ). Total parent assets.

- Solvency $\left(\operatorname{Solv}_{i}\right)$. Constructed as the ratio of bank equity to total assets.

- Parent bank liquidity ( Liquidity $_{i}$ ). Liquidity is measured as the sum of bank liquid assets relative to its total assets.

- External diversification $\left(\operatorname{Herf}_{i}\right)$. The parent bank's diversification of foreign affiliates around the globe is constructed as a Herfindahl index over total liabilities of affiliates across all countries in which such liabilities exist.

- Foreign owner $\left(\right.$ Fowner $\left._{i}\right)$. We distinguish between immediate owners from the United States or a foreign country using a dummy variable that takes the value of 1 if foreign. It would be expected that these are subsidiaries in the United States (branches are measured through alternative reporting) that have a primary focus on U.S. operations.

Finally, we introduce the variables that capture heterogeneity intra-bank in addition to inter-bank. As bank-country specific measures, we construct:

- Localfinance $_{i j}$. This variable is the local liability share in total local funding, and is intended to capture affiliate reliance on local deposits and other funding sources.

- Loanshare $_{i j}$. This variable captures the importance of each particular affiliate market to the total foreign lending of a parent bank. It is constructed as the ratio of total claims of bank $i$ in location $j$ to total claims over all locations.

In further refinements, we also construct two additional investment variables:

- Shortmaturity ${ }_{i j}$. This variable captures the ratio of maturities of claims less than one year relative to total claims. This is taken as one proxy for bank "commitment” to a market, 
with the possibility that mostly short maturity claims is indicative of a bank that is less invested in an affiliate market for the long haul.

- Outrisk $_{i j}$. Exploiting information contained in the regulatory data, we construct a variable capturing the fraction of total claims in a given location that are in fact guaranteed by entities in other foreign locations. For instance, a bank may finance a firm in a certain location, but this firm is a foreign subsidiary backed by the parent somewhere else, or it is a firm that is able to obtain a guarantee provided by a bank in another country. Either way, differentiating between claims in a given location that are truly local in nature as opposed to those that may be more "international”, may also give information regarding the bank's own commitment to that local market.

In all regression specifications, residuals are clustered by parent bank identity. Some regressions contain various groupings of explanatory variables or fixed effects. The relative importance of groups of variables are tested and interpreted. ${ }^{31}$

\section{$\underline{\text { III.4 Estimation Results }}$}

The econometric results are provided in Tables 3 through 10. Before turning to these results, it is useful to briefly place our methodology in the context of the prior literature. In general, studies of international transmission or country have a heavy emphasis on the countrylevel features that inform the channels and magnitudes of spillovers. Our approach includes some such variables $\bar{X}_{j}$ but these had very little explanatory power when introduced as freestanding determinants of changes in bank internal capital markets with affiliates. Building on the literature by adding groups of variables, we find there is some limited gain in explanatory power achieved when bank specific shocks are introduced in the OLS regressions and also interacted with the country variables. There was no incremental gain in the explanatory power of the regression by just adding in characteristics of parent banks $\bar{X}_{i}$. Throughout, the most significant

\footnotetext{
${ }^{31}$ If a latter period including a preponderance of government supports to individual banks were to be examined, other potential variables for inclusion could be the magnitude of the liquidity crunch and/or economic slowdown in each counterpart country and the amount of government support provided for the banking system during the crisis.
} 
power in the regressions arose from specifications that also contain the affiliate bank features $\bar{X}_{i j}$ that are the focus of our study (appendix Table 3). These bank variables are key for identifying the internal credit market supply consequences of a shock to parent banks. ${ }^{32}$

Tables 3 through 6 contain specifications associated with Shock1, in which the allocation of borrowing of bank affiliates in the pre-crisis period is compared with borrowing in the second half of 2007. The first two tables ( 3 and 4 ) contain the full cohort of reporting banks, regardless of whether these banks are U.S. owned or foreign owned. The next two tables (5 and 6) instead include only the U.S. owned reporting banks. Econometric results for the Shock2 period are provided in Tables 7 through 10, in which we compare the affiliate bank borrowing average quarterly patterns of the second half of 2007 with their average quarterly patterns in the first half of 2008. Below, we discuss the interpretation of the first set of tables and respective columns and then summarize findings from the remaining tables.

Beginning with Table 3 column (1), this most basic OLS regression specification considers whether the change in lending of banks affiliated with a parent with some degree of ABCP exposure was proportionate to that exposure after the dollar funding shock hit markets in the second half of 2007. The constant term is negative, suggesting that, on average, affiliates reduced net borrowing from the parent organization or increased net lending to the parent organization. The coefficient on Exposure suggests that this effect was smaller if banks had higher ex ante ABCP exposure. Recognizing that the OLS results may be biased due to correlated shocks within affiliate markets, column (2) provides the ABCP exposure coefficient under a regression specification that includes country fixed effects. The difference in this coefficient across specifications indicates that bias from the OLS specifications may be prevalent but is not large. We next consider whether the pattern of significance is instead better explained by introducing a range of variables capturing features of each bank in their respective affiliate markets. Columns (3) and (4) introduce the share of local liabilities in total liabilities by affiliate bank and the importance of that affiliate market in the total foreign lending of each parent bank. Column (4) provides the unbiased coefficients from specifications including affiliate market fixed effects. Note that the sample size is smaller in the fixed effect regressions. This occurs

\footnotetext{
${ }^{32}$ It is also the case that our identification strategy is geared toward exploiting fully the multi-dimensionality of the dataset. While the more aggregate country- or bank-specific variables are also more exposed to the issues of misidentification mentioned earlier, the dimensionality is possibly an important reason for their relatively small contribution to explaining the internal funding dynamics subject of our study.
} 
because the controls require us to drop any affiliate country in which there is only one U.S. parent bank in operation.

The key results of this table are robust across specifications. In response to the initial funding shock that hit parent banks, 1) on average all affiliates of U.S. banks reduced borrowing from the parent organization or increased lending to the parent organization; 2) the internal capital market response had differentiation across banks related to the size of the parent balance sheet shock; 3) more net outflows of funds came from those affiliates that relied more on locally raised liabilities (“core” funding markets); and 4) net outflows from affiliates were mitigated or even reversed for the affiliate markets that were larger in the overall foreign lending of U.S. global banks (“core” investment markets). The next table, Table 4, explores this net internal borrowing activity further, but now with the additional variables that permit the parent bank funding shock to interact with the country characteristics and the parent bank characteristics. The OLS specifications are provided in columns (1) to (3), and (5). Column (4) includes country fixed effects. Specification (5) introduces all of the same country and bank variables in levels, as well as interacting with the ABCP exposure term. The coefficients of the variables in levels (not interacted with Exposure) are not shown. These full specifications are presented in Appendix Table 4.

First, we observe that the combination of country and bank interactions provide little overall additional explanatory power to the entire regression. The main additional and robust insight is that the net borrowing of the affiliates were more protected or declined by less when the parent banking organizations were larger.

Tables 5 and 6 are results based on specifications excluding those U.S.-chartered banks that are subsidiaries of a foreign "higher holder" or parent. This exclusion allows for the possibility that the foreign-owned banks are different in that they could have access to a broader group of affiliates and internal capital market transfers that are beyond the scope of U.S. regulatory reporting requirements. All else equal, we might expect stronger results on the U.S.owned reporters for which we can observe the entire network of foreign banking affiliates. Table 5 shows a similar pattern of results to those in Table 3. As before, the average change in net borrowing by affiliates was (statistically) unchanged in the aftermath of the shock and differences across affiliates were similarly driven by the characteristics of the banks within the respective locations where they operated. The more liquid, ex ante, was the parent bank balance 
sheet, the more supported was the borrowing of the affiliates after the initial dollar funding shock. Table 6 also confirms the basic patterns observed in the previous tables. A comparison of the estimated coefficients seems to indicate slightly larger internal funding movements for the restricted set of U.S.-owned reporters.

What is the economic significance of the differences arising from the local finance and loan share variables? For this calculation, we use the results of column 4, Table 5 as a baseline. Starting with the local finance coefficient, we calculated the additional change in internal borrowing/lending for a bank at the $75^{\text {th }}$ percentile of the ABCP exposure distribution (a high exante $A B C P$ exposure bank), between a location at the $75^{\text {th }}$ percentile of the local finance distribution (a "core" local funding location for the banking organization) and a location at the $25^{\text {th }}$ percentile (a "periphery" funding location). The average Net Due value prior to the crisis for banks of high ex-ante Exposure, in relatively important local funding pool locations, was -\$1,094 million. In other words, the average high local funding pool location for such banks would carry a net claim vis-à-vis the rest of the banking organization of about one billion dollars. Performing the above mentioned exercise, we calculate that the location at the $75^{\text {th }}$ percentile of local finance expands its claim position by an additional $\$ 345$ million relative to the location at the $25^{\text {th }}$ percentile. Given the pre-crisis average position for such locations, relatively important local funding locations expanded their support to the rest of the organization by about 30 percent, a non-negligible contribution.

Likewise, we calculate the differential change in internal capital market flows for locations at the $75^{\text {th }}$ percentile of the loan share distribution (a core investment location) relative to locations at the $25^{\text {th }}$ percentile (a "periphery" location). The average Net Due value for core locations in pre-crisis quarters was $+\$ 1,902$ million, thus indicating that such locations would normally carry a net liability position vis-à-vis the rest of their organization. The computation indicates that during the first phase of the crisis, the core investment locations contribute about $\$ 168$ million less to the internal funding reallocation toward the rest of the organization, or about $9 \%$ of their pre-crisis position. Note that the positive sign for the loan share interaction may not imply an actual increase in internal borrowing for the core locations in response to the shock to the parent, but rather a contribution of lower degree by these locations to the overall support to the parent. 
The remaining tables consider the Shock2, which we interpret as a positive funding shock to parent banking organizations that followed the introduction of the Term Auction Facility. Indeed and consistent with this reversed direction of shock to parents, the response of net borrowing by affiliates was in the opposite direction than observed with Shock1. The pattern of effects on internal capital market reallocated was related to the very same bank and affiliate features: the initial "outflows" from affiliates were reversed in response to the innovation in funding availability for the parent through the Federal Reserve facilities (Table 7). One difference across the two shocks and evident in Table 8 is that parent bank solvency features played a more prominent role in the second shock. The higher the solvency of the parent, the more the affiliate continued to have access to net borrowing from the rest of the organization (or did not increase net lending to the rest of the organization). Additionally, this access was especially supported for parent banks with global lending operations that were more concentrated internationally (as indicated by the coefficients on the herfindahl index). In the U.S.-owned only sample, the results continue to suggest slightly larger effects (Table 9) and that better parent bank liquidity and solvency helped internal capital market flows vis-a-vis the foreign affiliates (Table 10).

We gauged the economic magnitude of the local finance and loan share variables for the second shock using the results in column 4, Table 9 as a baseline. On local finance, we calculate that in response to the positive funding shock to the parent during the first half of 2008, the location at the $75^{\text {th }}$ percentile of local finance received about $\$ 654$ million more funding than a location at the $25^{\text {th }}$ percentile (or it decreased its previous claim position by that amount). Given that the average Net Due value in the second half of 2007 for banks of high ex-ante exposure, in relatively important local funding pool locations, was $-\$ 2,534$ million, this differential effect amounts to about $25 \%$ of its previous position.

Similarly, in response to the second shock, core investment locations decreased their liability position by about $\$ 142$ million more than periphery locations. Given the average position by such locations in the second half of 2007 was about $+\$ 4,731$ million, the change corresponds to about 3\% of their previous position.

As a final note, we have performed various robustness checks to determine the sensitivity of these broad results to alternative measures of affiliate market importance in the parent bank's investment portfolio across foreign markets (not reported). Our results are robust to use of local 
claims, as opposed to local plus cross border claims, in the affiliate importance to the parent portfolio. Our results also are robust to adjustments for just the long maturity component of these loan portfolios and to adjustments for claims in a given foreign locations but that are backed by entities in other countries (hence a more "international” lending pool).

\section{Concluding remarks}

In the very early stages of the crisis, on balance and in aggregate, the foreign affiliates became net recipients of funds from their U.S.-based parents, as shown in Figure 5. After the Lehman failure and during the peak of the crisis, and again later in 2009, the foreign affiliates were conduits for inflows of funds to their parent organizations in the United States. This directional inflow into the United States through internal capital markets was reversed in 2010, when foreign affiliates relied more extensively on borrowing from their banking organizations.

Our empirical results shed light on the pattern of core and periphery affiliate markets that influence their relative roles in funding flows vis-à-vis the parents. This is important for understanding international shock transmission. Overall, given either a positive or a negative funding shock to the parent bank, funds are not reallocated to the same degree across all foreign affiliate markets. Among the core and periphery features of affiliate operations that we have identified are whether the affiliate operation relies on a local funding base and whether total cross-border and local lending to the affiliate market is substantial within the parent bank's portfolio. From the perspective of an overall affiliate market, macroeconomic transmission may be a function of the particular distribution of foreign banks engaged in their economy, the balance sheets of those foreign banks, and the ex ante features of the operations within the affiliate economy. Intra-bank funding flows can be a similar order of magnitude as the more frequently studies inter-bank funding markets, and we identify bank business models as important drivers of this intra-bank funding.

These types of considerations and issues related to global liquidity management by banking institutions are at the forefront of policy discourse. The need for global banks to enhance internal practices for the management of liquidity risk is one of the pillars enunciated by the Basel Committee on Banking Supervision in its renewed "Principles for Sound Liquidity Risk Management and Supervision” (BCBS, June 2008 and BCBS, December 2009). For instance: 
"Cross-entity funding channels are a mechanism through which liquidity pressures can spread through the group. An entity that provides regular funding to other entities of the group may be unable to continue providing this funding when it faces its own liquidity strain or when another entity is in need of extraordinary funding. For example, to mitigate the risk of contagion, a bank may establish internal limits on intragroup liquidity risk. A bank may also have limits at the subsidiary and branch level to restrict the reliance of related entities on funding from elsewhere in the bank. Internal limits also may be set for each currency used by a bank. The limits should be stricter where ready conversion between currencies is uncertain, particularly in stress situations.” (BCBS, December 2009, p. 23).

Increased emphasis on macro-prudential supervision and regulation can have direct repercussions on liquidity management practices by global banks and may lead to the introduction of possible guidelines and constraints to such practices. Changes in such practices may have the effect of altering the transmission of liquidity shocks across markets in ways that are not well-understood. Our analysis points to key bank and country features that have influenced transmission to date, with those features including the extent of local funding of affiliates and the importance of that affiliate market to the business of the banking organization. The results thus point at a significant management of liquidity on a global scale by banks with global operations, and at important idiosyncrasies, based on individual banks' choices in their global business model. These results have immediate normative implications, suggesting, for instance, that the patterns of international shock transmissions (through a global bank lending channel) would seem more the result of specific banks' operations and less due to common country factors. Of course, all of our results are drawn from a sample of banks that already have chosen to operate globally, and already have made decisions about the foreign markets in which they will operate. It is at that first stage of entry that the common country factors could be even more of a consideration. While our analysis does not speak to whether this global liquidity management potential that is being invoked has influenced the entry decision, presumably it has played some role. If global regulation changes, an open question is how the location and scope of internationalization of global banks likewise would adjust. 


\section{References:}

Acharya, Viral and Philipp Schnabl. 2010. "Do Global Banks Spread Global Imbalances? The Case of Asset-Backed Commercial Paper During the Financial Crisis of 2007-09." IMF Economic Review vol. 58 (1) pp .37-73 (August).

Ashcraft, Adam, 2008. “Are Bank Holding Companies a Source of Strength to Their Banking Subsidiaries?” Journal of Money, Credit, and Banking, Blackwell Publishing, vol. 40(2-3), pages 273-294, 03.

Armantier, Olivier, Sandy Krieger, and Jamie McAndrews, 2008. “The Federal Reserve’s Term Auction Facility”. Federal Reserve Bank of New York Current Issues in Economics and Finance, July vol.14 (5).

Bank for International Settlements, Committee on the Global Financial System, 2010. “The functioning and resilience of cross-border funding markets,” CGFS Publications no. 37 (March).

Barth, James, Gerard Caprio Jr., and Ross Levine, 2001. "The regulation and supervision of banks around the world - a new database," World Bank Policy Research Working Paper Series no. 2588 (April). 2008 database update and prior data at: http://econ.worldbank.org/WBSITE/EXTERNAL/EXTDEC/EXTRESEARCH/0,,contentMDK:2 0345037 pagePK:64214825 piPK:64214943 theSitePK:469382,00.html

Basel Committee on Banking Supervision in its renewed "Principles for Sound Liquidity Risk Management and Supervision” (BCBS, June 2008 and BCBS, December 2009).

Berger, A., DeYoung, R., Genay, H., Udell, G., 2000. Globalization of financial institutions: Evidence from cross-border banking performance. Brookings-Wharton Papers on Financial Services, 23-120.

Buch, Claudia, 2005. "Distance and International Banking," Review of International Economics, Blackwell Publishing, vol. 13(4), pages 787-804, 09.

Buch, Claudia, Catherine Tahmee Koch, and Michael Kotter. 2011. “Crises, Rescues, and Policy Transmission Through International Banks.” Manuscript (April).

Campello, Murillo, 2002. "Internal Capital Markets in Financial Conglomerates: Evidence from Small Bank Responses to Monetary Policy,” Journal of Finance, vol. 57(6), pages 2773-2805.

Cerutti, Eugenio, Giovanni Dell-Ariccia, and Maria Soledad Martinez Peria, 2007. "How Banks Go Abroad: Branches or Subsidiaries?” Journal of Banking and Finance, vol. 31(6), pages 16691692.

Cetorelli, Nicola and Linda Goldberg, "Banking Globalization, Monetary Transmission, and the Lending Channel,” forthcoming in the Journal of Finance. 
Cetorelli, Nicola and Linda Goldberg, 2011. "Global Banks and International Shock Transmission: Evidence from the Crisis,” International Monetary Fund Economic Review, vol. 59, pages 41-76.

Cetorelli, Nicola and Linda Goldberg. 2006. “Risks in U.S. Bank International Exposures,” in ed. Jerry Caprio, Douglas Evanoff and George Kaufman, Cross Border Banking: Regulatory Challenges (Singapore: World Scientific Publishing Company, Federal Reserve Bank of Chicago and World Bank).

Chinn, Menzie and Hiro Ito, 2008. “A New Measure of Financial Openness,” Journal of Comparative Policy Analysis, vol. 10(3), pages 307-320. Data: Chinn-Ito (2006) Financial Openness measure (data extending to 2008, updated July 2010).

Chinn, Menzie and Hiro Ito, 2006. "What Matters for Financial Development? Capital Controls, Institutions, and Interactions,” Journal of Development Economics, vol. 81(1), pages 163-192.

Claessens, Stijn and Neeltje van Horen, 2008. "Location Decisions of Foreign Banks and Institutional Competitive Advantage,” DNB Working Papers no. 172, Netherlands Central Bank.

Claessens, Stijn, Giovanni Dell’Ariccia, Deniz Igan, and Luc Laeven, 2010. "Cross-Country Experiences and Policy Implications from the Global Financial Crisis,” Economic Policy, vol. 25(62), pages 267-293.

De Haas, Ralph and Iman Lelyveld, 2009. "Internal Capital Markets and Lending by Multinational Bank Subsidiaries,” forthcoming in the Journal of Financial Intermediations.

Devereux, Michael and James Yetman. 2010. "Leverage constraints and the international transmission of shocks.” Journal of Money, Credit, and Banking vol. 42 pages 71-105.

Edwards, Sebastian, 2000. “Contagion,” The World Economy, vol. 23(7), pages 873-900.

Eichengreen, Barry, Ashoka Mody, Milan Nedeljkovic, and Lucio Sarno, 2009. "How the Subprime Crisis Went Global: Evidence from Bank Credit Default Swap Spreads.” NBER Working Paper no. 14904.

Fiechter, Jonathan, Inci Otker-Robe, Anna Ilyina, Michael Hsu, Andre Santos, and Jay Surti, 2011. “Subsidiaries or Branches: Does One Size Fit All?” IMF Staff Discussion Note SDN/11/04 (March).

Focarelli, Dario and Alberto Pozzolo, 2005. "Where Do Banks Expand Abroad? An Empirical Analysis,” Journal of Business, vol. 78(6), pages 2435-2464.

Forbes, Kristin and Menzie Chinn. 2004. “A decomposition of global linkages in financial markets over time.” The Review of Economics and Statistics vol 86 (3): 705-722 (August). 
Forbes, Kristin and Roberto Rigobon, 2002. "No Contagion, Only Interdependence: Measuring Stock Market Co-movements,” Journal of Finance, vol. 57(5), pages 2223-2261.

Giannetti, Mariassunta and Luc Laeven, 2011. "The Flight Home Effect: Evidence from the Syndicated Loan Market during Financial Crises,” Manuscript.

Goldberg, Linda, 2009. “Understanding Banking Sector Globalization,” International Monetary Fund Staff Papers, vol. 56, pages 171-197.

Goldberg, Linda, 2006. "The International Exposure of U.S. Banks: Europe and Latin America Compared," in International Capital Flows, Ed. Sebastian Edwards, NBER and University of Chicago Press.

Goldberg, Linda. 2002. "When is U.S. Bank Lending to Emerging Markets Volatile?” Preventing Currency Crises in Emerging Markets, eds. Sebastian Edwards and Jeffrey Frankel. (2002, NBER and University of Chicago Press.) NBER Working Paper \#8209 April 2001.

Goldberg, Linda, Craig Kennedy, and Jason Miu. 2011. Central Bank Dollar Swap Lines and Overseas Dollar Funding Costs” Economic Policy Review (May).

Goldberg, Linda and David Skeie "Why did US Branches of foreign banks borrow at the discount window during the crisis? http://libertystreeteconomics.newyorkfed.org/2011/04/whydid-us-branches-of-foreign-banks-borrow-at-the-discount-window-during-the-crisis.html

Houston, Joel, Christopher James, and David Marcus, 1997. "Capital market frictions and the role of internal capital markets in banking," Journal of Financial Economics, vol. 46(2), pages 135-164.

Imbs, Jean. 2004. "Trade, Finance, Specialization, and Synchronization." The Review of Economics and Statistics vol. 86 (3) pages 723-734 (August).

Ilzetski, Ethan, Carmen Reinhart, and Kenneth Rogoff (2009, 2011). “The country chronologies and background material to Exchange Rate Arrangements into the $21^{\text {st }}$ Century: Will the Anchor Currency Hold?”

International Monetary Fund, World Economic Outlook, April 2009.

Kamil, Herman and Kulwant Rai, 2010. “The Global Credit Crunch and Foreign Banks’ Lending to Emerging Markets: Why Did Latin America Fare Better?” IMF Working Paper WP/10/102.

Kashyap, Anil and Jeremy Stein, 2000. "What Do A Million Observations on Banks Say About the Transmission of Monetary Policy?” American Economic Review, vol. 90(3), pages 407-428.

Khwaja, Asim and Atif Mian, 2008. "Tracing the Impact of Bank Liquidity Shocks: Evidence from an Emerging Market,” American Economic Review, vol. 98(4), pages 1413-1442. 
Kose, Ayhan and Eswar Prasad, 2010. “Emerging Markets: Resilience and Growth Amid Global Turmoil,” Brookings Institution Press.

McGuire, Patrick and Goetz von Peter, "The US dollar shortage in global banking", BIS Quarterly Review, March 2009, 47-63.

Mian, Atif, 2006. "Distance Constraints: The Limits of Foreign Lending in Poor Economies,” The Journal of Finance, vol. 61(3), pages 1465-1505.

Mishkin, Frederic, 2009. "Why We Shouldn’t Turn Our Backs on Financial Globalization," International Monetary Fund Staff Papers, vol. 56(1), pages 139-170.

Parlour, Christine and Guillaume Plantin, 2008. “Loan Sales and Relationship Banking,” Journal of Finance, vol. 63(3), pages 1291-1314.

Peek, Joe and Eric Rosengren, 1997. "The International Transmission of Financial Shocks: The Case of Japan,” American Economic Review, vol. 87(4), pages 495-505.

Peek, Joe and Eric Rosengren, 1997. "Collateral Damage: Effects of the Japanese Bank Crisis on Real Activity in the United States", The American Economic Review, March 2000, 30-45.

Prasad, Eswar, Kenneth Rogoff, Shang-Jin Wei, and M. Ayhan Kose, 2003. "Effects of Financial Globalization on Developing Countries: Some Empirical Evidence,” IMF Occasional Paper no. 220.

Prasad, Eswar, Kenneth Rogoff, Shang-Jin Wei, and M. Ayhan Kose, 2007. "Financial Globalization, Growth, and Volatility in Developing Countries," in editor Ann Harrison Globalization and Poverty (NBER and University of Chicago Press).

Rose, Andrew and Mark Spiegel, 2011. "Cross-Country Causes and Consequences of the Crisis: An Update,” European Economic Review, vol. 55(3), pages 309-324.

Rose, Andrew and Mark Spiegel, 2009. "International Financial Remoteness and Macroeconomic Volatility,” Journal of Development Economics, vol. 89(2), pages 250-257.

Rose, Andrew and Tomasz Wieladek. 2011. “Financial Protectionism”. NBER working paper 17073.

Santor, Eric, 2004. “Contagion and the Composition of Canadian Banks' Foreign Asset Portfolios: Do Crises Matter?” Manuscript, Bank of Canada.

Schnabl, Philipp, 2009. "Financial Globalization and the Transmission of Credit Supply Shocks: Evidence from an Emerging Market,” New York University Working Paper no. FIN-08-088.

Stein, Jeremy, 1997. "Internal Capital Markets and the Competition for Corporate Resources,” Journal of Finance, vol. 52(1), pages 111-133. 
Stein, Jeremy, 2002. "Information Production and Capital Allocation: Decentralized versus Hierarchical Firms,” Journal of Finance, vol. 57(5), pages 1891-1921.

Van Rijckeghem, Caroline and Beatrice Weder, 2001. "Sources of Contagion: Is it Finance or Trade,” Journal of International Economics, vol. 54(2), pages 293-308.

Van Rijckeghem, Caroline and Beatrice Weder, 2003. "Spillovers through Banking Centers: A Panel Data Analysis of Bank Flows,” Journal of International Money and Finance, vol. 22(4), pages 483-509.

Zorome, Ahmed, 2007. "Concept of Offshore Financial Centers: In Search of an Operational Definition,” IMF Working Paper WP/07/87. 
Table 1 Counts of U.S. banks that have foreign affiliates

\begin{tabular}{lccccc} 
& 2006q1 & 2007q1 & 2008q1 & 2009q1 & 2010q1 \\
ALL banks & & & & & \\
\hline Total & 42 & 41 & 39 & 43 & 44 \\
US-owned & 27 & 26 & 26 & 25 & 25 \\
foreign-owned & 15 & 15 & 13 & 18 & 19 \\
\hline
\end{tabular}

Source: Authors' computations based on FFIEC 009 reporting by quarter. 
Table 2: Basic Balance Sheet Information of U.S. Banks with Foreign Affiliates

\begin{tabular}{|c|c|c|c|c|c|c|}
\hline \multirow{2}{*}{ Statistics on U.S. Banking Organization } & \multicolumn{2}{|c|}{$\begin{array}{l}\text { 2006Q1-2007Q2 } \\
\text { (Avg) }\end{array}$} & \multicolumn{2}{|c|}{$2009 Q 2$} & \multicolumn{2}{|c|}{$2010 Q 2$} \\
\hline & median & mean & median & mean & median & mean \\
\hline Bank asset size (billions USD) ${ }^{1}$ & 53.4 & 198.5 & 64.6 & 253.9 & 66.2 & 262.5 \\
\hline Bank solvency ratio $(\%)^{2}$ & 8.8 & 10.0 & 9.4 & 10.5 & 9.9 & 11.0 \\
\hline Foreign loans / Assets $(\%)^{3}$ & 2.0 & 3.7 & 1.4 & 3.5 & 0.9 & 3.0 \\
\hline Bank liquid assets / Total assets $(\%)^{4}$ & 2.3 & 5.0 & 2.5 & 4.4 & 2.6 & 4.9 \\
\hline Absolute value of Total Net Due / Assets (\%) & 2.3 & 7.3 & 1.3 & 9.9 & 1.4 & 6.8 \\
\hline \multicolumn{7}{|l|}{$\begin{array}{l}\text { Statistics computed by Bank, across Foreign Affiliates: } \\
\text { Compared across all bank-affiliate observations }\end{array}$} \\
\hline Number of affiliates per parent bank & 2 & 13 & 2 & 13 & 2 & 12 \\
\hline \multicolumn{7}{|l|}{ Affiliate Liabilities: } \\
\hline Locally raised / Total within country $(\%)^{6}$ & 81.2 & 63.3 & 68.2 & 56.7 & 74.5 & 60.1 \\
\hline \multicolumn{7}{|l|}{ Affiliate Assets: } \\
\hline Local claims in country / Total local claims across all countries $(\%)^{7}$ & 0.06 & 4.9 & 0.05 & 4.9 & 0.05 & 5.5 \\
\hline Long-term total claims in country / All total claims in country (\%) & 11.9 & 27.7 & 16.2 & 30.8 & 11.7 & 27.5 \\
\hline Outward risk transfer / All total claims in country $(\%)^{9}$ & 6.5 & 19.8 & 4.9 & 19.4 & 3.6 & 17.5 \\
\hline Number of parent banks or bank holding companies & \multirow{2}{*}{\multicolumn{2}{|c|}{$\begin{array}{c}44 \\
566\end{array}$}} & \multirow{2}{*}{\multicolumn{2}{|c|}{$\begin{array}{c}43 \\
540\end{array}$}} & \multirow{2}{*}{\multicolumn{2}{|c|}{$\begin{array}{c}44 \\
540\end{array}$}} \\
\hline Number of bank-affiliate country observations & & & & & & \\
\hline
\end{tabular}

\footnotetext{
Source: Quarterly Call Report forms, FR Y-9C, and FFIEC 009.
}

Note: ${ }^{1}$ Bank asset size is constructed from series RCFD2170 of the call reports and BHCK2170 of FRY-9C. ${ }^{2}$ Solvency is the ratio of equity (RCFD3210, BHDM3210) to bank asset size. ${ }^{3}$ Foreign loans are from series RCFN2122 of the call reports. (Note that no equivalents series are available for BHCs, which make up approximately $35 \%$ of the sample.) ${ }^{4}$ Liquid assets are the sum of total held-to maturity securities (RCFD1754, BHCK1754), total trading asset (RCFD3545, BHCK3545), and federal funds sold and securities purchased under agreements to resell (RCFD1350, BHCK1350). ${ }^{5}$ Net due figures are from Column 4 of FFIEC009 Schedule1a. ${ }^{6}$ Local liabilities figures are the sum of foreign-office liability in non-local currency and in local currency (Column 1 and 2 of FFIEC009 Schedule1a). Total liabilities are the sum of local liabilities plus net due inflows (positive values of Column 4 of FFIEC009 Schedule1a). ${ }^{7}$ All claims reported in the table are on immediate counterparty basis. Local claims are the sum of foreign-office claims on local residents in non-local currency by sectors and in local currency (Columns 4, 5, 6, 8 of FFIEC009 Schedule1), and cross border claims are the sum of cross-border claims by sectors (Columns 1-3 of FFIEC009 Schedule1). ${ }^{8}$ Long-term claims are computed as the difference of total local/cross-border claims and claims of remaining maturity up to and including 1 year (Column 7 of FFIEC009 Schedule1). ${ }^{9}$ Outward risk transfer (Columns 9-11 of FFIEC009 Schedule1) shows all claims subject to risk transfers from immediate counterparty basis to ultimate risk basis. 


\section{Table 3 \\ Net Internal Borrowing Dynamics During the Crisis - Shock1 All U.S. Reporting Banks}

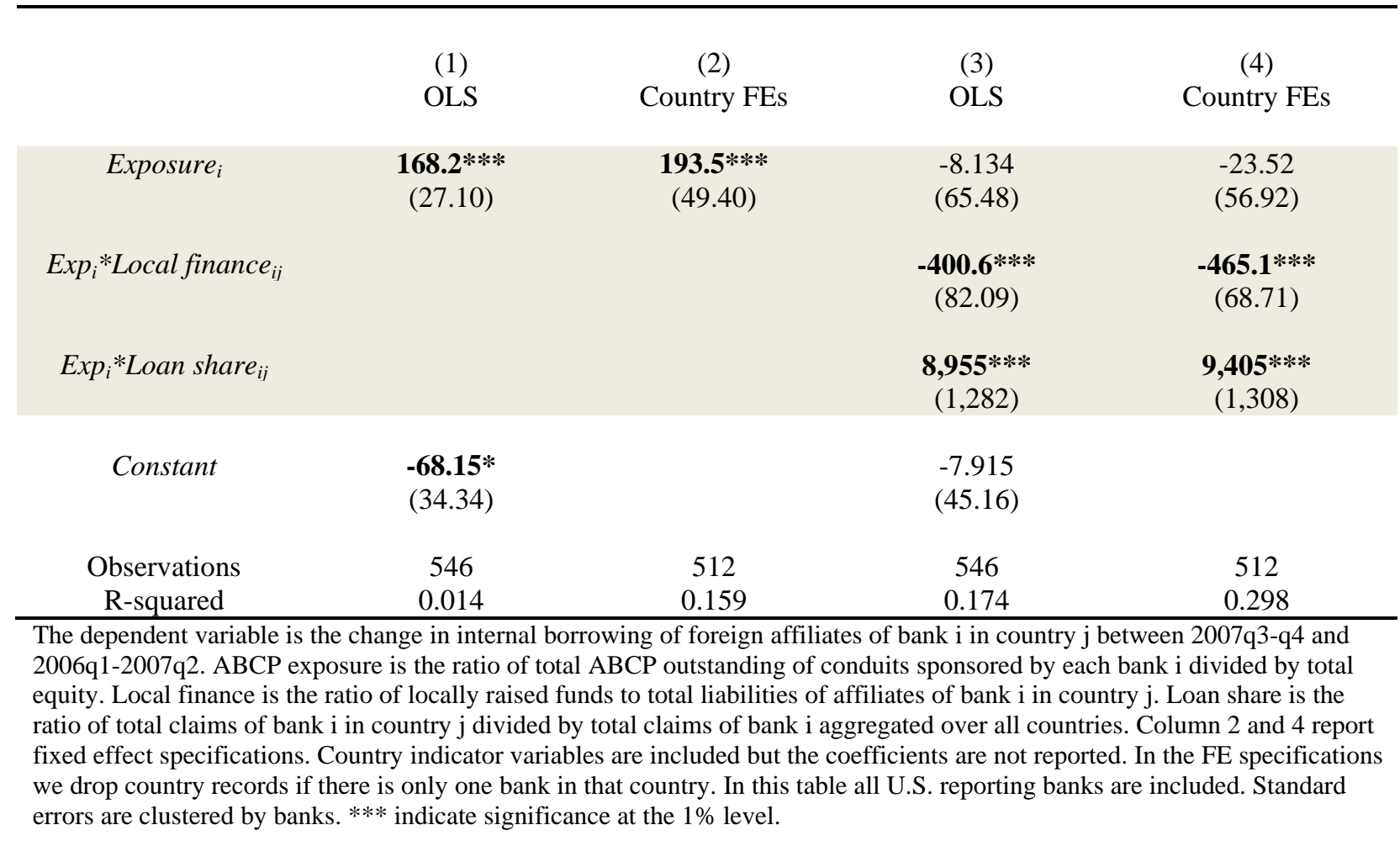




\section{Table 4 Net Internal Borrowing Dynamics During the Crisis - Shock1 All U.S. Reporting Banks, Country and Bank Controls}

\begin{tabular}{|c|c|c|c|c|c|}
\hline & $\begin{array}{c}\text { (1) } \\
\text { OLS } \\
\text { Country controls }\end{array}$ & $\begin{array}{c}\text { (2) } \\
\text { OLS } \\
\text { Bank controls }\end{array}$ & $\begin{array}{c}\text { (3) } \\
\text { OLS } \\
\begin{array}{c}\text { Country and Bank } \\
\text { controls }\end{array}\end{array}$ & $\begin{array}{c}\text { (4) } \\
\text { Country FE } \\
\text { Country and Bank } \\
\text { controls }\end{array}$ & $\begin{array}{c}\text { (5) } \\
\text { OLS } \\
\text { Level controls } \\
\text { included }\end{array}$ \\
\hline Exposure $_{i}$ & $\begin{array}{l}-535.0 \\
(796.2)\end{array}$ & $\begin{array}{c}-406.2 \\
(466.3)\end{array}$ & $\begin{array}{l}-1,615 \\
(1,488)\end{array}$ & $\begin{array}{c}-1,392 \\
(1,485)\end{array}$ & $\begin{array}{l}-4,223^{*} \\
(2,219)\end{array}$ \\
\hline Exp $_{i}{ }^{*}$ Local finance $_{i j}$ & $\begin{array}{c}-313.6 * * \\
(132.4)\end{array}$ & $\begin{array}{c}\mathbf{- 8 4 9 . 2 * * *} \\
(270.7)\end{array}$ & $\begin{array}{c}\mathbf{- 8 9 0 . 3 * * *} \\
(305.3)\end{array}$ & $\begin{array}{c}\mathbf{- 8 1 1 . 6 * * *} \\
(263.2)\end{array}$ & $\begin{array}{c}-\mathbf{9 0 8 . 4} * * * \\
(322.0)\end{array}$ \\
\hline Exp $_{i}{ }^{*}$ Loan share $_{i j}$ & $\begin{array}{c}\mathbf{8 , 8 6 5 * * *} \\
(1,458)\end{array}$ & $\begin{array}{c}\mathbf{1 0 , 6 0 3} * * * \\
(1,167)\end{array}$ & $\begin{array}{c}\mathbf{1 0 , 8 6 3 * * *} \\
(1,317)\end{array}$ & $\begin{array}{c}\mathbf{1 0 , 4 8 3} * * * \\
(1,276)\end{array}$ & $\begin{array}{c}\mathbf{1 0 , 8 6 6 * * *} \\
(1,328)\end{array}$ \\
\hline \multicolumn{6}{|l|}{ Country variables } \\
\hline $\operatorname{Exp}_{i}{ }^{*} O F C_{j}$ & $\begin{array}{c}-92.80 \\
(115.4)\end{array}$ & & $\begin{array}{c}20.27 \\
(66.98)\end{array}$ & $\begin{array}{c}59.38 \\
(55.32)\end{array}$ & $\begin{array}{c}\text { 88.08** } \\
(42.75)\end{array}$ \\
\hline $\operatorname{Exp}_{i}{ }^{*}$ kaopen $_{j}$ & $\begin{array}{c}-6.343 \\
(33.51)\end{array}$ & & $\begin{array}{l}-0.0642 \\
(38.80)\end{array}$ & $\begin{array}{c}20.51 \\
(42.17)\end{array}$ & $\begin{array}{c}5.486 \\
(20.21)\end{array}$ \\
\hline $\operatorname{Exp}_{i}{ }^{*}$ ldistnyc $_{j}$ & $\begin{array}{c}62.21 \\
(90.07)\end{array}$ & & $\begin{array}{c}158.2 \\
(127.7)\end{array}$ & $\begin{array}{c}100.7 \\
(115.3)\end{array}$ & $\begin{array}{c}108.6 \\
(94.25)\end{array}$ \\
\hline Exp $_{i} * e^{2 x a t e} e_{j}$ & $\begin{array}{l}\text { 80.73* } \\
(42.31)\end{array}$ & & $\begin{array}{c}-80.40 \\
(131.1)\end{array}$ & $\begin{array}{c}34.24 \\
(157.8)\end{array}$ & $\begin{array}{c}-39.86 \\
(134.4)\end{array}$ \\
\hline \multicolumn{6}{|l|}{ Bank variables } \\
\hline $\operatorname{Exp}_{i} *$ Total asset $_{i}$ & & $\begin{array}{c}\mathbf{0 . 3 0 4 * *} \\
(0.128)\end{array}$ & $\begin{array}{c}\mathbf{0 . 4 5 7 * * *} \\
(0.160)\end{array}$ & $\begin{array}{l}\text { 0.376* } \\
(0.203)\end{array}$ & $\begin{array}{l}0.0791 \\
(0.296)\end{array}$ \\
\hline $\operatorname{Exp}_{i}{ }^{*}$ Liquidity $_{i}$ & & $\begin{array}{c}1,171 \\
(1,379)\end{array}$ & $\begin{array}{c}762.5 \\
(1,576)\end{array}$ & $\begin{array}{c}1,114 \\
(2,464)\end{array}$ & $\begin{array}{l}13,844 \\
(8,342)\end{array}$ \\
\hline 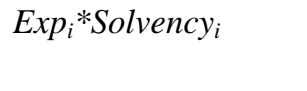 & & $\begin{array}{c}5,344 \\
(4,287)\end{array}$ & $\begin{array}{c}3,567 \\
(4,592)\end{array}$ & $\begin{array}{c}5,476 \\
(7,503)\end{array}$ & $\begin{array}{l}\text { 32,642* } \\
(17,610)\end{array}$ \\
\hline $\operatorname{Exp}_{i}{ }^{*}$ Herfindhal $_{i}$ & & $\begin{array}{l}-709.4 \\
(627.4)\end{array}$ & $\begin{array}{l}-680.4 \\
(822.8)\end{array}$ & $\begin{array}{l}-185.5 \\
(1,274)\end{array}$ & $\begin{array}{l}-391.7 \\
(1,393)\end{array}$ \\
\hline Constant & $\begin{array}{l}-6.103 \\
(44.65)\end{array}$ & $\begin{array}{l}\mathbf{- 8 9 . 8 5 *} \\
(53.33)\end{array}$ & $\begin{array}{c}-90.88 \\
(54.79)\end{array}$ & & $\begin{array}{c}-381.6 \\
(829.0)\end{array}$ \\
\hline Observations & 500 & 546 & 500 & 475 & 500 \\
\hline R-squared & 0.193 & 0.202 & 0.234 & 0.332 & 0.244 \\
\hline
\end{tabular}

The dependent variable is the change in internal borrowing of foreign affiliates of bank $i$ in country $j$ between 2007q3-q4 and 2006q1-2007q2. ABCP exposure is the ratio of total ABCP outstanding of conduits sponsored by each bank i divided by total equity. Local finance is the ratio of locally raised funds to total liabilities of affiliates of bank $i$ in country $j$. Loan share is the ratio of total claims of bank i in country j divided by total claims of bank i aggregated over all countries. Column 4 reports fixed effect specifications. Country indicator variables are included but the coefficients are not reported. In the FE specifications we drop country records if there is only one bank in that country. Column 5 reports results of a specification where all country and bank variables were included in levels (non interacted) as well, but the coefficients are not reported. Full set of results from such specifications are reported in Appendix Table 1. In this table all U.S. reporting banks are included. Standard errors are clustered by banks. *** indicate significance at the $1 \%$ level. 


\section{Table 5 Net Internal Borrowing Dynamics During the Crisis - Shock1 Only U.S. Owned Banks}

\begin{tabular}{|c|c|c|c|c|}
\hline & $\begin{array}{l}(1) \\
\text { OLS }\end{array}$ & $\begin{array}{c}(2) \\
\text { Country FEs }\end{array}$ & $\begin{array}{l}\text { (3) } \\
\text { OLS }\end{array}$ & $\begin{array}{c}(4) \\
\text { Country FEs }\end{array}$ \\
\hline Exposure $_{i}$ & $\begin{array}{c}\text { 184.8*** } \\
(18.98)\end{array}$ & $\begin{array}{c}209.7 * * * \\
(34.25)\end{array}$ & $\begin{array}{l}-18.90 \\
(64.97)\end{array}$ & $\begin{array}{l}-35.91 \\
(55.34)\end{array}$ \\
\hline Exp $_{i}{ }^{*}$ Local finance $_{i j}$ & & & $\begin{array}{c}-425.4^{* * *} \\
(90.09)\end{array}$ & $\begin{array}{c}-520.3^{* * *} \\
(85.45)\end{array}$ \\
\hline Exp $_{i}{ }^{*}$ Loan share ${ }_{i j}$ & & & $\begin{array}{c}\mathbf{9 , 9 1 8 * * *} \\
(578.6)\end{array}$ & $\begin{array}{c}\text { 10,279*** } \\
(515.2)\end{array}$ \\
\hline Constant & $\begin{array}{l}-77.64 * \\
(39.31)\end{array}$ & & $\begin{array}{c}5.187 \\
(52.64)\end{array}$ & \\
\hline Observations & 464 & 430 & 464 & 430 \\
\hline R-squared & 0.017 & 0.252 & 0.192 & 0.400 \\
\hline \multicolumn{5}{|c|}{$\begin{array}{l}\text { The dependent variable is the change in internal borrowing of foreign affiliates of bank } \mathrm{i} \text { in country j between 2007q3-q4 and } \\
\text { 2006q1-2007q2. ABCP exposure is the ratio of total ABCP outstanding of conduits sponsored by each bank i divided by total } \\
\text { equity. Local finance is the ratio of locally raised funds to total liabilities of affiliates of bank i in country j. Loan share is the } \\
\text { ratio of total claims of bank i in country j divided by total claims of bank } i \text { aggregated over all countries. Column } 2 \text { and } 4 \text { report } \\
\text { fixed effect specifications. Country indicator variables are included but the coefficients are not reported. In the FE specifications } \\
\text { we drop country records if there is only one bank in that country. In this table regressions were run on the subset of U.S.-owned } \\
\text { banks. Standard errors are clustered by banks. *** indicate significance at the } 1 \% \text { level. }\end{array}$} \\
\hline
\end{tabular}




\section{Table 6 Net Internal Borrowing Dynamics During the Crisis - Shock1 Only U.S. Owned Banks, Country and Bank Controls}

\begin{tabular}{|c|c|c|c|c|c|}
\hline & $\begin{array}{c}\text { (1) } \\
\text { OLS } \\
\text { Country controls }\end{array}$ & $\begin{array}{c}\text { (2) } \\
\text { OLS } \\
\text { Bank controls }\end{array}$ & $\begin{array}{c}\text { (3) } \\
\text { OLS } \\
\text { Country and Bank } \\
\text { controls }\end{array}$ & $\begin{array}{c}\text { (4) } \\
\text { Country FE } \\
\text { Country and Bank } \\
\text { controls }\end{array}$ & $\begin{array}{c}\text { (5) } \\
\text { OLS } \\
\text { Level controls } \\
\text { included }\end{array}$ \\
\hline Exposure $_{i}$ & $\begin{array}{c}-599.8 \\
(1,037)\end{array}$ & $\begin{array}{c}-3,660 \\
(3,807)\end{array}$ & $\begin{array}{c}-5,603 \\
(4,445)\end{array}$ & $\begin{array}{c}-2,562 \\
(2,902)\end{array}$ & $\begin{array}{c}-7,307 * * \\
(3,291)\end{array}$ \\
\hline Exp $_{i}{ }^{*}$ Local finance $_{i j}$ & $\begin{array}{c}-337.5^{* *} \\
(144.1)\end{array}$ & $\begin{array}{c}-\mathbf{1 , 0 1 4} * * * \\
(357.1)\end{array}$ & $\begin{array}{c}\mathbf{- 1 , 1 2 8 * *} \\
(433.6)\end{array}$ & $\begin{array}{c}-\mathbf{1 , 0 6 2 * *} \\
(385.5)\end{array}$ & $\begin{array}{c}-1,100 * * \\
(422.1)\end{array}$ \\
\hline $\operatorname{Exp}_{i}{ }^{*}$ Loan share $_{i j}$ & $\begin{array}{c}\text { 9,857*** } \\
(785.9)\end{array}$ & $\begin{array}{c}\mathbf{1 2 , 0 3 2} * * * \\
(1,223)\end{array}$ & $\begin{array}{c}\mathbf{1 2 , 5 4 0 * * *} \\
(1,351)\end{array}$ & $\begin{array}{c}11,993 * * * \\
(1,067)\end{array}$ & $\begin{array}{c}\mathbf{1 2 , 4 5 4 * * *} \\
(1,315)\end{array}$ \\
\hline \multicolumn{6}{|l|}{ Country variables } \\
\hline $\operatorname{Exp}_{i}{ }^{*} O F C_{j}$ & $\begin{array}{l}-100.5 \\
(133.6)\end{array}$ & & $\begin{array}{c}6.630 \\
(70.64)\end{array}$ & $\begin{array}{c}91.49 * * \\
(41.77)\end{array}$ & $\begin{array}{c}92.43 * * \\
(42.52)\end{array}$ \\
\hline $\operatorname{Exp}_{i}{ }^{*}$ kaopen $_{i}$ & $\begin{array}{c}-6.983 \\
(39.07)\end{array}$ & & $\begin{array}{c}14.86 \\
(40.24)\end{array}$ & $\begin{array}{c}21.90 \\
(36.59)\end{array}$ & $\begin{array}{c}4.144 \\
(22.17)\end{array}$ \\
\hline $\operatorname{Exp}_{i}{ }^{*}$ ldistnyc $_{j}$ & $\begin{array}{c}68.26 \\
(117.6)\end{array}$ & & $\begin{array}{l}\text { 255.8* } \\
(147.5)\end{array}$ & $\begin{array}{c}118.9 * * \\
(44.20)\end{array}$ & $\begin{array}{l}\text { 139.0* } \\
(76.66)\end{array}$ \\
\hline Exp $_{i} *$ exrate $_{j}$ & $\begin{array}{c}95.47 * * \\
(37.09)\end{array}$ & & $\begin{array}{l}-112.6 \\
(159.9)\end{array}$ & $\begin{array}{c}39.43 \\
(188.8)\end{array}$ & $\begin{array}{l}-13.79 \\
(132.4)\end{array}$ \\
\hline \multicolumn{6}{|l|}{ Bank variables } \\
\hline Exp $_{i} *$ Total asset $_{i}$ & & $\begin{array}{c}1.563 \\
(1.289)\end{array}$ & $\begin{array}{c}1.772 \\
(1.308)\end{array}$ & $\begin{array}{c}1.126 \\
(1.031)\end{array}$ & $\begin{array}{l}-0.0172 \\
(1.394)\end{array}$ \\
\hline $\operatorname{Exp}_{i}{ }^{*}$ Liquidity $_{i}$ & & $\begin{array}{l}3,477 * \\
(1,723)\end{array}$ & $\begin{array}{l}\mathbf{2 , 9 4 2 *} \\
(1,712)\end{array}$ & $\begin{array}{c}1,283 \\
(1,101)\end{array}$ & $\begin{array}{l}25,215^{*} \\
(14,491)\end{array}$ \\
\hline Exp $_{i}{ }^{*}$ Solvency $_{i}$ & & $\begin{array}{c}-6,564 \\
(5,674)\end{array}$ & $\begin{array}{c}\mathbf{- 1 0 , 0 6 1 *} \\
(5,782)\end{array}$ & $\begin{array}{l}-6,972 \\
(5,633)\end{array}$ & $\begin{array}{c}37,974 \\
(35,644)\end{array}$ \\
\hline $\operatorname{Exp}_{i}{ }^{*}$ Herfindhal $_{i}$ & & $\begin{array}{c}24,071 \\
(25,006)\end{array}$ & $\begin{array}{c}24,135 \\
(24,804)\end{array}$ & $\begin{array}{c}11,467 \\
(19,510)\end{array}$ & $\begin{array}{c}10,227 \\
(22,422)\end{array}$ \\
\hline Constant & $\begin{array}{c}7.221 \\
(51.30)\end{array}$ & $\begin{array}{l}-81.06 \\
(52.19)\end{array}$ & $\begin{array}{l}-78.43 \\
(52.01)\end{array}$ & & $\begin{array}{c}-891.3 \\
(1,199)\end{array}$ \\
\hline Observations & 423 & 464 & 423 & 398 & 423 \\
\hline R-squared & 0.215 & 0.234 & 0.277 & 0.451 & 0.291 \\
\hline \multicolumn{6}{|c|}{$\begin{array}{l}\text { The dependent variable is the change in internal borrowing of foreign affiliates of bank i in country j between } 2007 q 3-q 4 \text { and } \\
2006 q 1-2007 q 2 \text {. ABCP exposure is the ratio of total ABCP outstanding of conduits sponsored by each bank i divided by total } \\
\text { equity. Local finance is the ratio of locally raised funds to total liabilities of affiliates of bank i in country j. Loan share is the } \\
\text { ratio of total claims of bank i in country j divided by total claims of bank } \mathrm{i} \text { aggregated over all countries. Column } 4 \text { reports fixed } \\
\text { effect specifications. Country indicator variables are included but the coefficients are not reported. In the FE specifications we } \\
\text { drop country records if there is only one bank in that country. Column } 5 \text { reports results of a specification where all country and } \\
\text { bank variables were included in levels (non interacted) as well, but the coefficients are not reported. Full set of results from such } \\
\text { specifications are reported in Appendix Table } 1 \text {. In this table regressions were run on the subset of U.S.-owned banks. Standard } \\
\text { errors are clustered by banks. *** indicate significance at the } 1 \% \text { level. }\end{array}$} \\
\hline
\end{tabular}




\section{Table 7 Net Internal Borrowing Dynamics During the Crisis - Shock 2}

All U.S. Reporting Banks

\begin{tabular}{|c|c|c|c|c|}
\hline & $\begin{array}{c}(1) \\
\text { OLS }\end{array}$ & $\begin{array}{c}(2) \\
\text { Country FEs }\end{array}$ & $\begin{array}{c}(3) \\
\text { OLS }\end{array}$ & $\begin{array}{c}\text { (4) } \\
\text { Country FEs }\end{array}$ \\
\hline Exposure $_{i}$ & $\begin{array}{l}-14.09 \\
(26.66)\end{array}$ & $\begin{array}{c}8.306 \\
(40.63)\end{array}$ & $\begin{array}{l}-13.74 \\
(46.77)\end{array}$ & $\begin{array}{c}59.21 \\
(40.44)\end{array}$ \\
\hline Exp $_{i}{ }^{*}$ Local finance $_{i j}$ & & & $\begin{array}{l}780.0 * * \\
(289.5)\end{array}$ & $\begin{array}{c}\text { 872.4*** } \\
(247.3)\end{array}$ \\
\hline Exp $_{i}^{*}$ Loan share $i j$ & & & $\begin{array}{c}-\mathbf{6 , 3 3 3} * * * \\
(1,574)\end{array}$ & $\begin{array}{c}-7,912 * * * \\
(1,252)\end{array}$ \\
\hline Constant & $\begin{array}{c}\text { 92.73** } \\
(37.21)\end{array}$ & & $\begin{array}{c}14.07 \\
(55.03)\end{array}$ & \\
\hline Observations & 559 & 525 & 559 & 525 \\
\hline R-squared & 0.000 & 0.075 & 0.118 & 0.218 \\
\hline \multicolumn{5}{|c|}{$\begin{array}{l}\text { The dependent variable is the change in internal borrowing of foreign affiliates of bank i in country j between } 2008 \mathrm{q} 1-\mathrm{q} 2 \text { and } \\
2007 \mathrm{q} 3-\mathrm{q} 4 \text {. ABCP exposure is the ratio of total ABCP outstanding of conduits sponsored by each bank i divided by total equity. } \\
\text { Local finance is the ratio of locally raised funds to total liabilities of affiliates of bank i in country j. Loan share is the ratio of } \\
\text { total claims of bank i in country j divided by total claims of bank i aggregated over all countries. Column } 2 \text { and } 4 \text { report fixed } \\
\text { effect specifications. Country indicator variables are included but the coefficients are not reported. In the FE specifications we } \\
\text { drop country records if there is only one bank in that country. In this table all U.S. reporting banks are included. Standard errors } \\
\text { are clustered by banks. *** indicate significance at the } 1 \% \text { level. }\end{array}$} \\
\hline
\end{tabular}




\section{Table 8 Net Internal Borrowing Dynamics During the Crisis - Shock 2 All U.S. Reporting Bank, Country and Bank Controls}

\begin{tabular}{|c|c|c|c|c|c|}
\hline & $\begin{array}{c}\text { (1) } \\
\text { OLS } \\
\text { Country controls }\end{array}$ & $\begin{array}{c}(2) \\
\text { OLS } \\
\text { Bank controls }\end{array}$ & $\begin{array}{c}\text { (3) } \\
\text { OLS } \\
\begin{array}{c}\text { Country and Bank } \\
\text { controls }\end{array}\end{array}$ & $\begin{array}{c}(4) \\
\text { Country FE } \\
\text { Country and Bank } \\
\text { controls }\end{array}$ & $\begin{array}{c}\text { (5) } \\
\text { OLS } \\
\text { Level controls }\end{array}$ \\
\hline Exposure $_{i}$ & $\begin{array}{c}3,757 * * * \\
(1,349)\end{array}$ & $\begin{array}{c}-\mathbf{1 , 3 8 4 * * *} \\
(427.2)\end{array}$ & $\begin{array}{l}2,895^{*} \\
(1,527)\end{array}$ & $\begin{array}{l}3,269 * \\
(1,798)\end{array}$ & $\begin{array}{c}\mathbf{4 , 8 2 7 * * *} \\
(1,544)\end{array}$ \\
\hline Exp $_{i}{ }^{*}$ Local finance $_{i j}$ & $\begin{array}{l}\text { 646.4* } \\
(356.0)\end{array}$ & $\begin{array}{c}\text { 1,122*** } \\
(194.3)\end{array}$ & $\begin{array}{c}\text { 1,104*** } \\
(278.4)\end{array}$ & $\begin{array}{c}1,072 * * * \\
(273.0)\end{array}$ & $\begin{array}{c}\text { 1,123*** } \\
(275.2)\end{array}$ \\
\hline Exp $_{i}{ }^{*}$ Loan share ${ }_{i j}$ & $\begin{array}{c}-\mathbf{6 , 2 7 5 * * *} \\
(1,717)\end{array}$ & $\begin{array}{c}-\mathbf{7 , 0 9 6 * * *} \\
(1,550)\end{array}$ & $\begin{array}{c}-\mathbf{7 , 2 7 9 * * *} \\
(1,751)\end{array}$ & $\begin{array}{c}-\mathbf{8 , 2 8 3} * * * \\
(1,450)\end{array}$ & $\begin{array}{c}-7,310 * * * \\
(1,734)\end{array}$ \\
\hline \multicolumn{6}{|l|}{ Country variables } \\
\hline $\operatorname{Exp}_{i}{ }^{*} O F C_{j}$ & $\begin{array}{c}337.2 \\
(291.8)\end{array}$ & & $\begin{array}{l}187.0 \\
(231.7)\end{array}$ & $\begin{array}{c}157.5 \\
(249.7)\end{array}$ & $\begin{array}{c}164.1 \\
(208.8)\end{array}$ \\
\hline Exp $_{i}{ }^{*}$ kaopen $_{i}$ & $\begin{array}{l}-71.98 \\
(75.32)\end{array}$ & & $\begin{array}{l}-85.16 \\
(71.64)\end{array}$ & $\begin{array}{l}-117.3 \\
(90.87)\end{array}$ & $\begin{array}{l}-94.13 \\
(65.33)\end{array}$ \\
\hline $\operatorname{Exp}_{i}{ }^{*}$ ldistnyc $_{j}$ & $\begin{array}{c}-432.9 * * * \\
(146.4)\end{array}$ & & $\begin{array}{c}-502.4 * * * \\
(168.6)\end{array}$ & $\begin{array}{c}-553.8 * * * \\
(174.3)\end{array}$ & $\begin{array}{c}-472.7 * * * \\
(143.7)\end{array}$ \\
\hline Exp $_{i}{ }^{*}$ exrate $_{j}$ & $\begin{array}{l}-9.296 \\
(232.6)\end{array}$ & & $\begin{array}{c}79.07 \\
(171.3)\end{array}$ & $\begin{array}{l}181.3 \\
(213.9)\end{array}$ & $\begin{array}{c}144.3 \\
(144.1)\end{array}$ \\
\hline \multicolumn{6}{|l|}{ Bank variables } \\
\hline Exp $_{i} *$ Total asset ${ }_{i}$ & & $\begin{array}{c}-\mathbf{0 . 2 2 9} * * \\
(0.103)\end{array}$ & $\begin{array}{c}-\mathbf{0 . 2 8 7 * *} \\
(0.109)\end{array}$ & $\begin{array}{c}-0.242^{* *} \\
(0.118)\end{array}$ & $\begin{array}{c}-\mathbf{0 . 6 9 3} * * * \\
(0.110)\end{array}$ \\
\hline $\operatorname{Exp}_{i}{ }^{*}$ Liquidity $_{i}$ & & $\begin{array}{l}2,545 * \\
(1,397)\end{array}$ & $\begin{array}{c}2,483 \\
(1,546)\end{array}$ & $\begin{array}{c}2,945 \\
(2,128)\end{array}$ & $\begin{array}{c}-3,194 \\
(3,054)\end{array}$ \\
\hline $\operatorname{Exp}_{i}{ }^{*}$ Solvency ${ }_{i}$ & & $\begin{array}{c}9,922 * * * \\
(3,048)\end{array}$ & $\begin{array}{c}\text { 11,540*** } \\
(3,639)\end{array}$ & $\begin{array}{c}\text { 14,074** } \\
(5,331)\end{array}$ & $\begin{array}{l}-3,435 \\
(5,532)\end{array}$ \\
\hline $\operatorname{Exp}_{i}{ }^{*}$ Herfindhal $_{i}$ & & $\begin{array}{c}\mathbf{1 , 6 7 7 * * *} \\
(577.0)\end{array}$ & $\begin{array}{c}\text { 1,642**** } \\
(598.7)\end{array}$ & $\begin{array}{c}1,003 \\
(778.7)\end{array}$ & $\begin{array}{l}-30.68 \\
(929.2)\end{array}$ \\
\hline Constant & $\begin{array}{c}0.456 \\
(65.18)\end{array}$ & $\begin{array}{l}\text { 73.33* } \\
(38.83)\end{array}$ & $\begin{array}{l}\text { 68.03* } \\
(37.43)\end{array}$ & & $\begin{array}{c}120.9 \\
(376.5)\end{array}$ \\
\hline Observations & 513 & 559 & 513 & 488 & 513 \\
\hline R-squared & 0.154 & 0.140 & 0.186 & 0.267 & 0.195 \\
\hline \multicolumn{6}{|c|}{$\begin{array}{l}\text { The dependent variable is the change in internal borrowing of foreign affiliates of bank } \mathrm{i} \text { in country j between } 2008 \mathrm{q} 1-\mathrm{q} 2 \text { and } \\
\text { 2007q3-q4. ABCP exposure is the ratio of total ABCP outstanding of conduits sponsored by each bank i divided by total equity. } \\
\text { Local finance is the ratio of locally raised funds to total liabilities of affiliates of bank i in country j. Loan share is the ratio of } \\
\text { total claims of bank i in country j divided by total claims of bank } \mathrm{i} \text { aggregated over all countries. Column } 4 \text { reports fixed effect } \\
\text { specifications. Country indicator variables are included but the coefficients are not reported. In the FE specifications we drop } \\
\text { country records if there is only one bank in that country. Column } 5 \text { reports results of a specification where all country and bank } \\
\text { variables were included in levels (non interacted) as well, but the coefficients are not reported. Full set of results from such } \\
\text { specifications are reported in Appendix Table } 1 \text {. In this table all U.S. reporting banks are included. Standard errors are clustered } \\
\text { by banks. *** indicate significance at the } 1 \% \text { level. }\end{array}$} \\
\hline
\end{tabular}




\section{Table 9 Net Internal Borrowing Dynamics During the Crisis - Shock 2 Only U.S. Owned Banks}

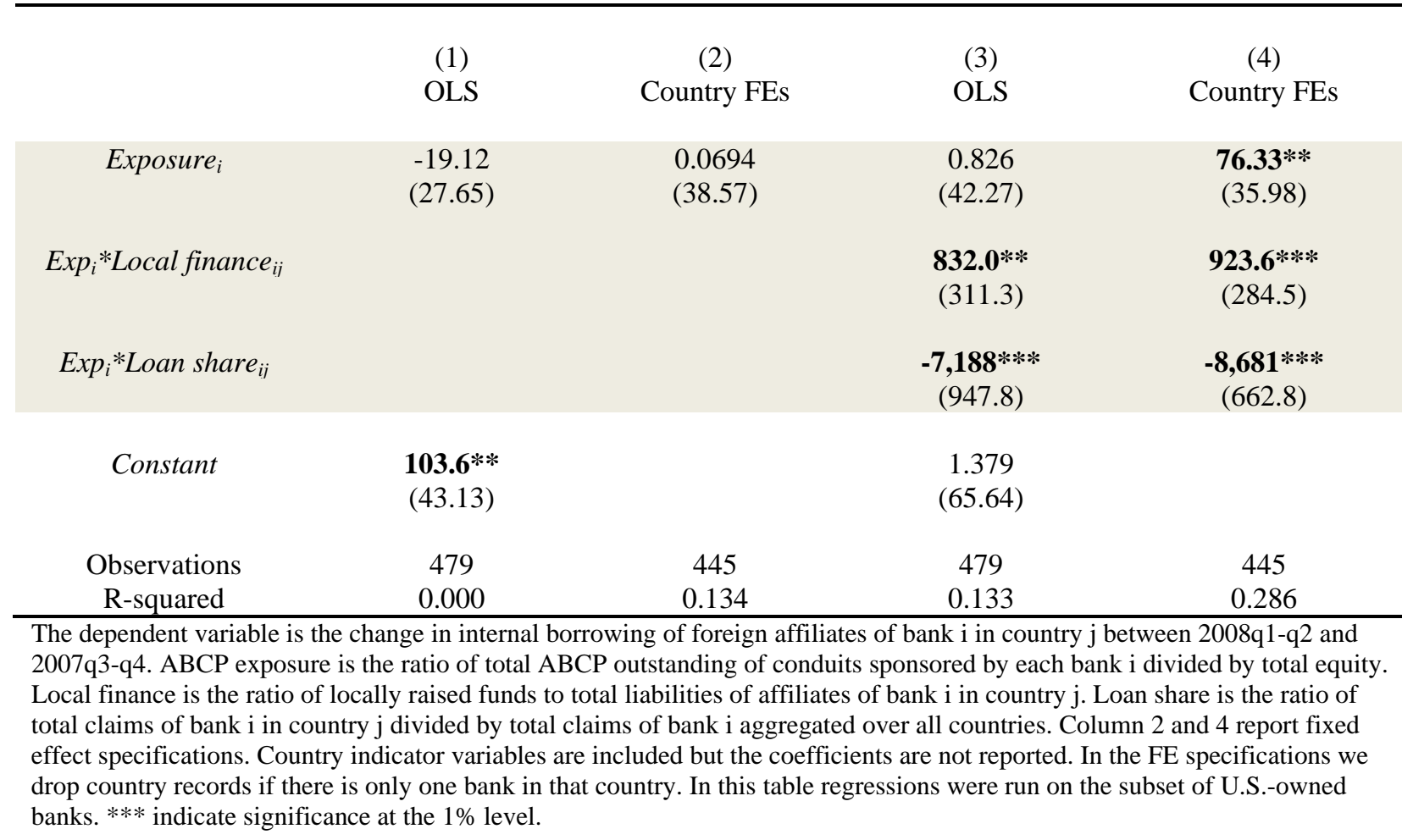


Table 10 Net Internal Borrowing Dynamics During the Crisis - Shock 2 Only U.S. Owned Banks, Country and Bank Controls

\begin{tabular}{|c|c|c|c|c|c|}
\hline & $\begin{array}{c}\text { (1) } \\
\text { OLS } \\
\text { Country controls }\end{array}$ & $\begin{array}{c}\text { (2) } \\
\text { OLS } \\
\text { Bank controls }\end{array}$ & $\begin{array}{c}\text { (3) } \\
\text { OLS } \\
\text { Country and Bank } \\
\text { controls }\end{array}$ & $\begin{array}{c}(4) \\
\text { Country FE } \\
\text { Country and Bank } \\
\text { controls }\end{array}$ & $\begin{array}{c}\text { (5) } \\
\text { OLS } \\
\text { Level controls }\end{array}$ \\
\hline Exposure $_{i}$ & $\begin{array}{c}\mathbf{4 , 7 0 6 * * *} \\
(1,132)\end{array}$ & $\begin{array}{l}-2,565^{*} \\
(1,486)\end{array}$ & $\begin{array}{c}1,508 \\
(1,850)\end{array}$ & $\begin{array}{l}-1,643 \\
(2,104)\end{array}$ & $\begin{array}{c}2,273 \\
(1,572)\end{array}$ \\
\hline Exp $_{i}{ }^{*}$ Local finance $_{i j}$ & $\begin{array}{l}\text { 713.9* } \\
(381.2)\end{array}$ & $\begin{array}{c}\mathbf{1 , 2 6 1} * * * \\
(116.9)\end{array}$ & $\begin{array}{c}\text { 1,307*** } \\
(144.1)\end{array}$ & $\begin{array}{c}\mathbf{1 , 2 8 2} * * * \\
(131.1)\end{array}$ & $\begin{array}{c}\text { 1,310*** } \\
(148.3)\end{array}$ \\
\hline Exp $_{i}{ }^{*}$ Loan share ${ }_{i j}$ & $\begin{array}{c}-\mathbf{7 , 1 7 0 * * *} \\
(1,077)\end{array}$ & $\begin{array}{c}\mathbf{- 8 , 1 5 1 * * *} \\
(816.1)\end{array}$ & $\begin{array}{c}\mathbf{- 8 , 4 7 9 * * *} \\
(863.5)\end{array}$ & $\begin{array}{c}-\mathbf{9 , 4 9 0 * * *} \\
(520.4)\end{array}$ & $\begin{array}{c}\mathbf{- 8 , 4 7 1 * * *} \\
(884.1)\end{array}$ \\
\hline \multicolumn{6}{|l|}{ Country variables } \\
\hline $\operatorname{Exp}_{i} * O F C_{j}$ & $\begin{array}{c}406.2 \\
(332.5)\end{array}$ & & $\begin{array}{c}225.1 \\
(260.1)\end{array}$ & $\begin{array}{c}72.19 \\
(199.1)\end{array}$ & $\begin{array}{c}135.9 \\
(224.0)\end{array}$ \\
\hline Exp $_{i}{ }^{*}$ kaopen $_{j}$ & $\begin{array}{l}-96.68 \\
(74.62)\end{array}$ & & $\begin{array}{l}-118.3 \\
(71.16)\end{array}$ & $\begin{array}{l}-\mathbf{1 2 0 . 5 *} \\
(59.33)\end{array}$ & $\begin{array}{l}-108.1 \\
(66.26)\end{array}$ \\
\hline $\operatorname{Exp}_{i}{ }^{*}$ ldistnyc $_{j}$ & $\begin{array}{c}-538.0 * * * \\
(122.4)\end{array}$ & & $\begin{array}{c}-\mathbf{6 2 9 . 2 * * *} \\
(164.8)\end{array}$ & $\begin{array}{c}-597.1 * * * \\
(101.7)\end{array}$ & $\begin{array}{c}-591.7 * * * \\
(149.1)\end{array}$ \\
\hline Exp $_{i}^{*}$ exrate $_{j}$ & $\begin{array}{l}-36.68 \\
(246.4)\end{array}$ & & $\begin{array}{c}74.83 \\
(161.9)\end{array}$ & $\begin{array}{c}200.0 \\
(225.4)\end{array}$ & $\begin{array}{c}176.8 \\
(125.4)\end{array}$ \\
\hline \multicolumn{6}{|l|}{ Bank variables } \\
\hline 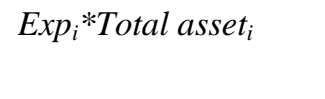 & & $\begin{array}{l}-0.0193 \\
(0.305)\end{array}$ & $\begin{array}{c}0.138 \\
(0.250)\end{array}$ & $\begin{array}{c}0.661 \\
(0.494)\end{array}$ & $\begin{array}{l}-0.272 \\
(0.308)\end{array}$ \\
\hline Exp $_{i}{ }^{*}$ Liquidity $_{i}$ & & $\begin{array}{c}1,489 \\
(1,197)\end{array}$ & $\begin{array}{l}\mathbf{2 , 6 0 1 * *} \\
(961.9)\end{array}$ & $\begin{array}{c}\mathbf{6 , 0 3 0} * * * \\
(1,850)\end{array}$ & $\begin{array}{c}3,229 \\
(2,983)\end{array}$ \\
\hline Exp $_{i}{ }^{*}$ Solvency $_{i}$ & & $\begin{array}{c}\mathbf{2 8 , 6 8 7 * * *} \\
(4,602)\end{array}$ & $\begin{array}{c}33,900 * * * \\
(3,642)\end{array}$ & $\begin{array}{c}\mathbf{4 3 , 8 4 5 * * *} \\
(6,080)\end{array}$ & $\begin{array}{c}32,702 * * * \\
(7,465)\end{array}$ \\
\hline $\operatorname{Exp}_{i} *$ Herfindhal $_{i}$ & & $\begin{array}{l}-405.0 \\
(4,939)\end{array}$ & $\begin{array}{c}4,061 \\
(3,917)\end{array}$ & $\begin{array}{l}12,629 \\
(8,607)\end{array}$ & $\begin{array}{c}-791.4 \\
(4,879)\end{array}$ \\
\hline Constant & $\begin{array}{l}-13.41 \\
(74.54)\end{array}$ & $\begin{array}{c}20.89 \\
(32.12)\end{array}$ & $\begin{array}{c}33.48 \\
(30.10)\end{array}$ & & $\begin{array}{c}310.8 \\
(578.5)\end{array}$ \\
\hline Observations & 438 & 479 & 438 & 413 & 438 \\
\hline R-squared & 0.180 & 0.169 & 0.230 & 0.353 & 0.233 \\
\hline \multicolumn{6}{|c|}{$\begin{array}{l}\text { The dependent variable is the change in internal borrowing of foreign affiliates of bank i in country j between 2008q1-q2 and } \\
2007 q 3-q 4 \text {. ABCP exposure is the ratio of total ABCP outstanding of conduits sponsored by each bank i divided by total equity. } \\
\text { Local finance is the ratio of locally raised funds to total liabilities of affiliates of bank i in country j. Loan share is the ratio of } \\
\text { total claims of bank i in country j divided by total claims of bank } i \text { aggregated over all countries. Column } 4 \text { reports fixed effect } \\
\text { specifications. Country indicator variables are included but the coefficients are not reported. In the FE specifications we drop } \\
\text { country records if there is only one bank in that country. Column } 5 \text { reports results of a specification where all country and bank } \\
\text { variables were included in levels (non interacted) as well, but the coefficients are not reported. Full set of results from such } \\
\text { specifications are reported in Appendix Table } 1 \text {. In this table regressions were run on the subset of U.S.-owned banks. *** } \\
\text { indicate significance at the } 1 \% \text { level. }\end{array}$} \\
\hline
\end{tabular}


Figure 1: Number of U.S. Banks with Affiliates in Countries

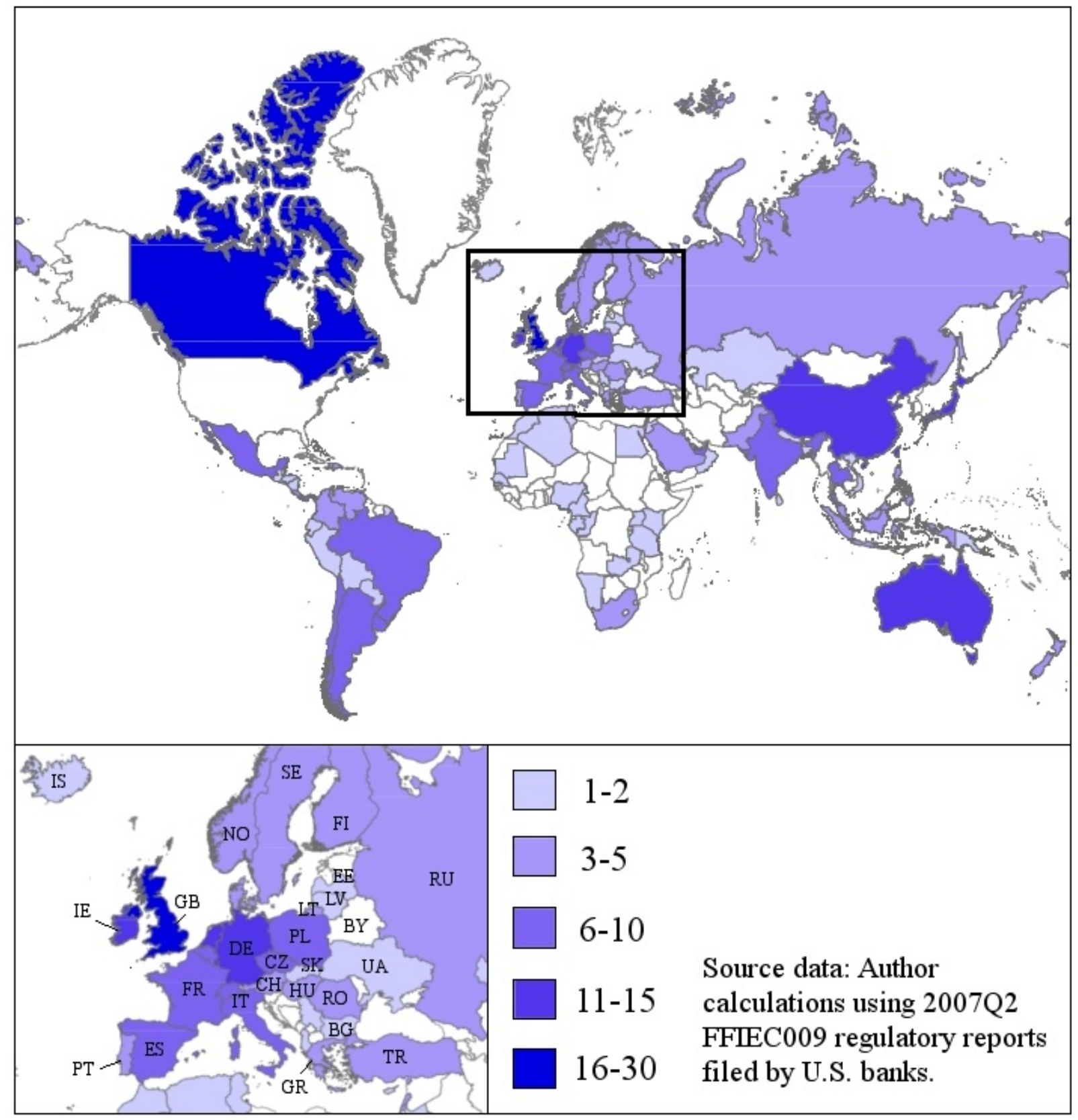


Figure 2: Value of U.S. Bank Affiliate Liabilities in Countries (Billion US \$)

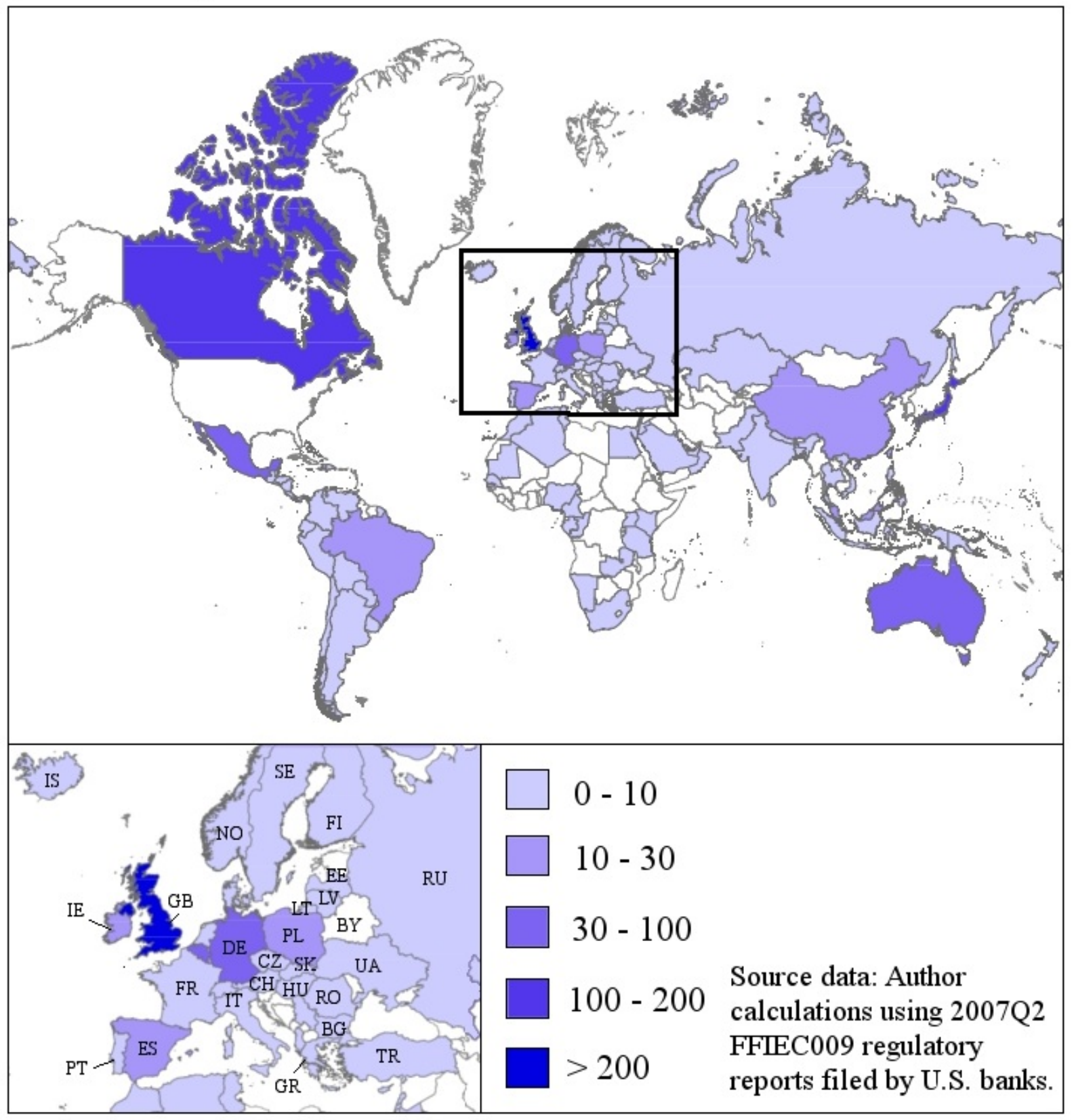


Figure 3 Intra-bank and Interbank Flows of U.S. Banks

Billions USD

Billions USD

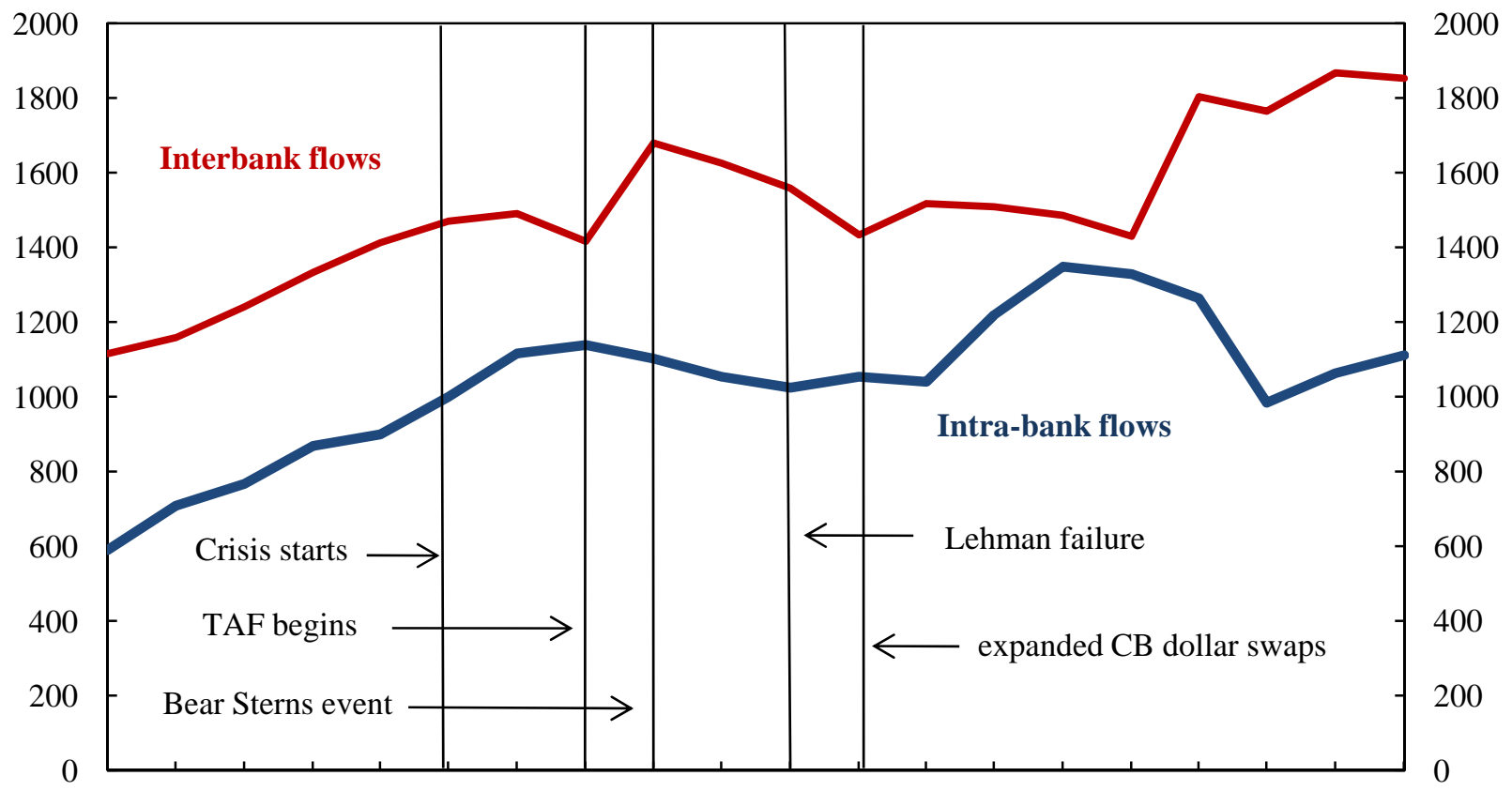

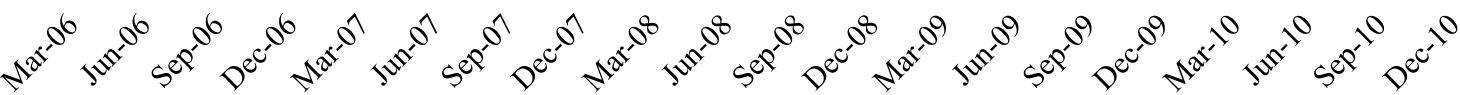

Source: FFIEC 009 and BIS Consolidated Banking Statistics

Note: Intra-bank flows are computed as the sum of net due to (from) of affiliates (in absolute value), from FFIEC 009. Interbank flows are computed as the sum of foreign claims of the U.S. vis-a-vis rest of world and of rest of world vis-a-vis the U.S., from BIS. 
Figure 4 Benchmark dollar funding rates Relative to Overnight Indexed Swaps Spread of One Month Rates to OIS

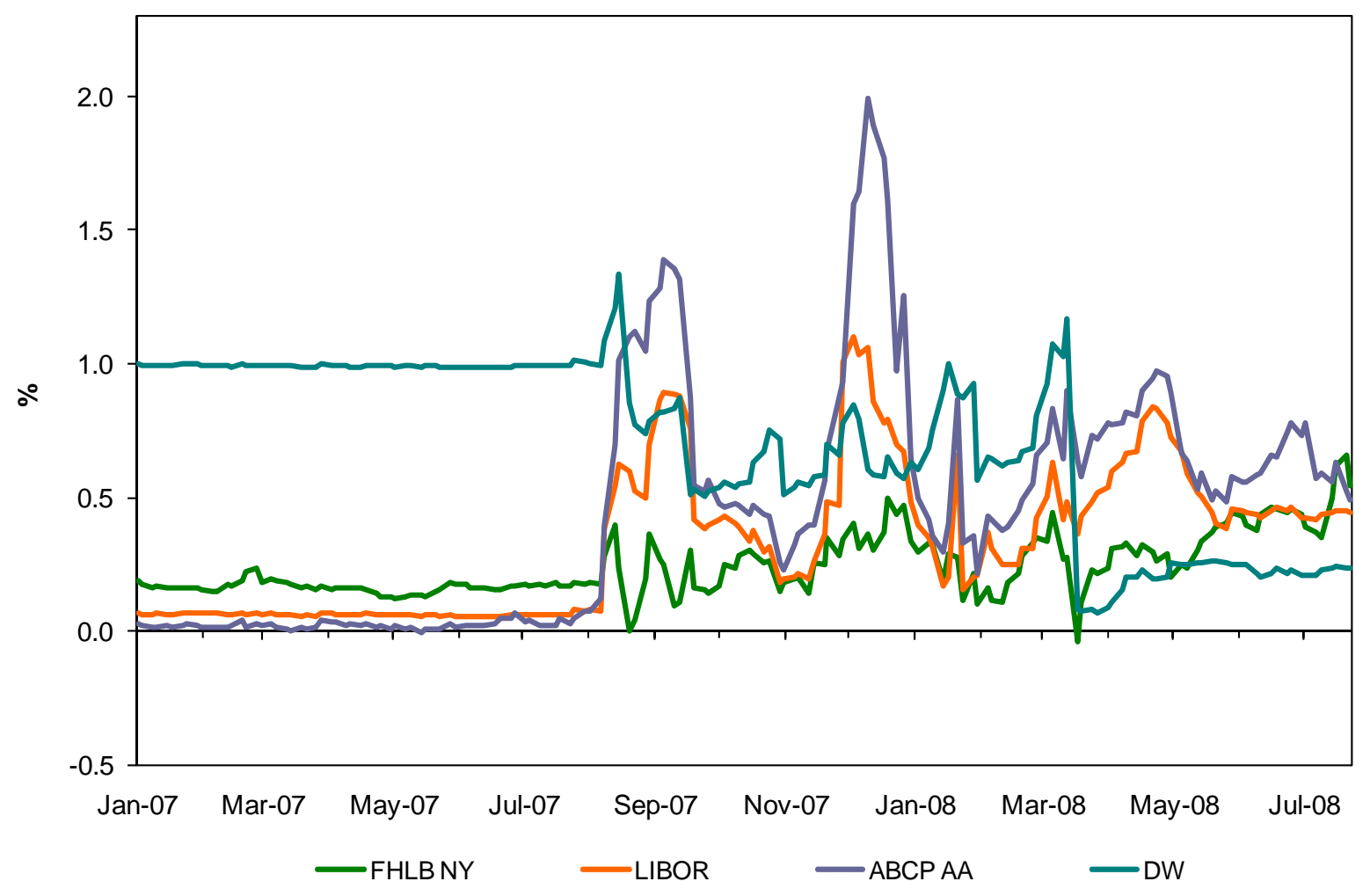


Figure 5 Net Related Borrowing by Overseas Affiliates of U.S. Banks

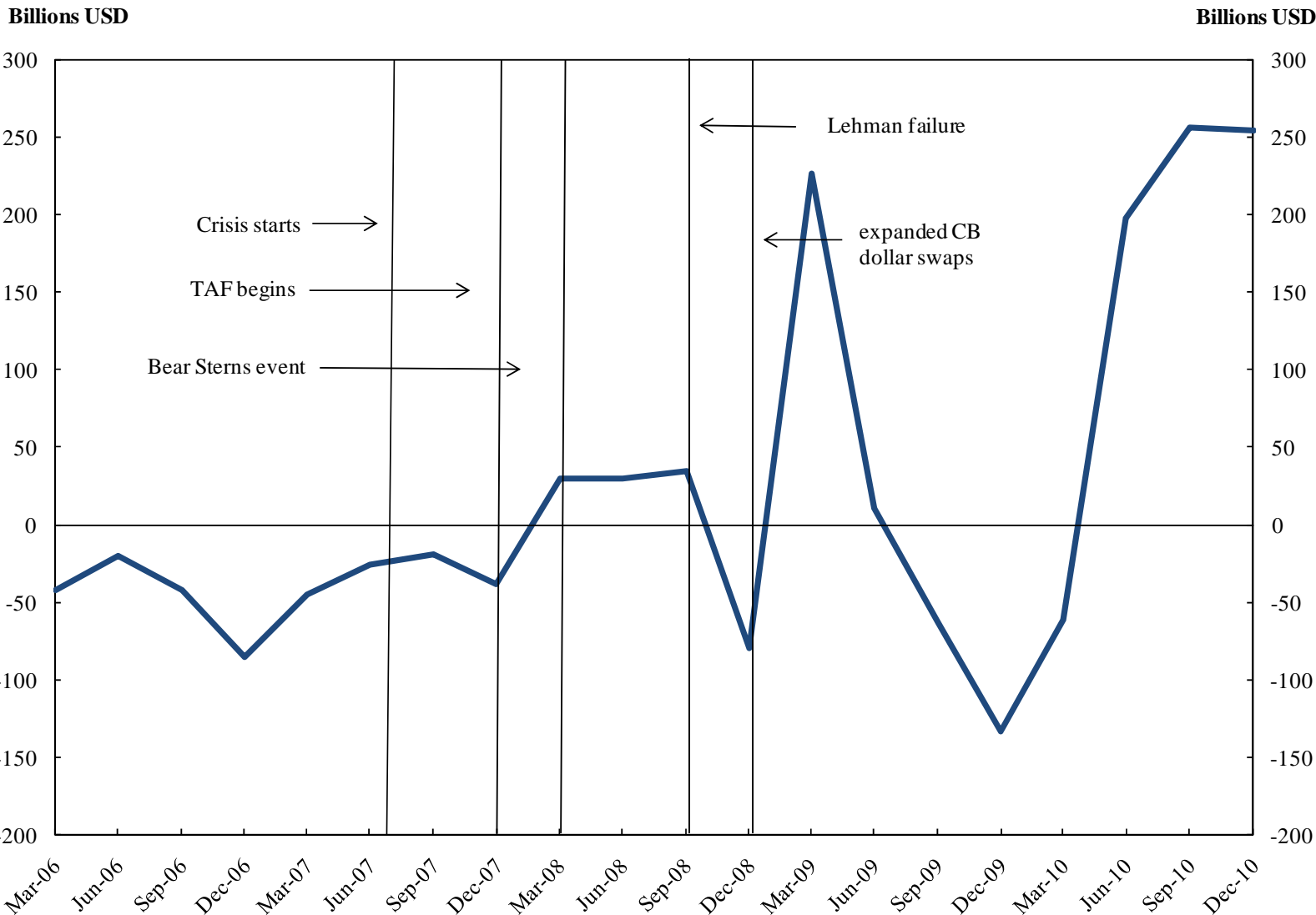

Source: Authors' construction using FFIEC 009 data across U.S. reporting banks.

Sample of banks excludes new reporters as of 2008Q1 and 2009Q1 and banks that entered the sample only for a single period. 


\section{Appendix Table 1 Countries (of 121) and Affiliates of U.S. Banks in Sample, By Country}

\begin{tabular}{|c|c|c|c|c|c|}
\hline Affiliate country & $\begin{array}{c}\text { Counts } \\
\text { (avg) }\end{array}$ & Affiliate country & $\begin{array}{c}\text { Counts } \\
\text { (avg) }\end{array}$ & Affiliate country & $\begin{array}{c}\text { Counts } \\
\text { (avg) }\end{array}$ \\
\hline Albania & 1 & Grenada & 1 & Palau & 1 \\
\hline Algeria & 1 & Guatemala & 2 & Panama & 8 \\
\hline Argentina & 9 & Haiti & 1 & Papua New Guinea & 1 \\
\hline Australia & 11 & Honduras & 2 & Paraguay & 2 \\
\hline Austria & 4 & Hong Kong & 14 & Peru & 2 \\
\hline British West Indies & 8 & Hungary & 4 & Philippines & 5 \\
\hline Bahamas & 11 & Iceland & 1 & Poland & 6 \\
\hline Bahrain & 4 & India & 8 & Portugal & 4 \\
\hline Bangladesh & 2 & Indonesia & 4 & Qatar & 2 \\
\hline Barbados & 5 & Ireland & 12 & Romania & 3 \\
\hline Belgium & 8 & Israel & 4 & Russia & 4 \\
\hline Belize & 1 & Italy & 9 & Saudi Arabia & 4 \\
\hline Bermuda & 9 & Ivory Coast & 1 & Senegal & 1 \\
\hline Bolivia & 1 & Jamaica & 2 & Serbia And Montenegro & 1 \\
\hline Bosnia And Herzegovina & 1 & Japan & 11 & Seychelles & 1 \\
\hline Brazil & 8 & Jordan & 2 & Singapore & 12 \\
\hline Brunei & 1 & Kazakhstan & 2 & Slovakia & 2 \\
\hline Bulgaria & 2 & Kenya & 1 & South Africa & 4 \\
\hline Cameroon & 1 & Korea & 10 & Spain & 10 \\
\hline Canada & 21 & Kuwait & 3 & Sri Lanka & 1 \\
\hline Cayman Islands & 30 & Latvia & 1 & Sweden & 5 \\
\hline Channel Islands \& Isle Of Man & 8 & Lebanon & 3 & Switzerland & 7 \\
\hline Chile & 7 & Lithuania & 1 & Taiwan & 10 \\
\hline China & 11 & Luxembourg & 12 & Tanzania & 1 \\
\hline Colombia & 5 & Macau & 2 & Thailand & 6 \\
\hline Congo, Democratic Rep. & 1 & Malaysia & 5 & Trinidad & 2 \\
\hline Costa Rica & 3 & Malta & 1 & Trinidad And Tobago & 3 \\
\hline Cyprus & 2 & Mauritania & 1 & Tunisia & 1 \\
\hline Czech Republic & 6 & Mauritius & 5 & Turkey & 5 \\
\hline Denmark & 4 & Mexico & 10 & Uganda & 1 \\
\hline Dominican Republic & 4 & Monaco & 2 & Ukraine & 2 \\
\hline Ecuador & 2 & Morocco & 1 & United Arab Emirates & 6 \\
\hline Egypt & 2 & Namibia & 1 & United Kingdom & 18 \\
\hline El Salvador & 2 & Nepal & 1 & Uruguay & 8 \\
\hline Finland & 4 & Netherlands & 11 & Venezuela & 4 \\
\hline France & 1 & Netherlands Antilles & 5 & Vietnam & 2 \\
\hline French Guiana & 8 & New Zealand & 5 & Zambia & 1 \\
\hline French West Indies & 1 & Nicaragua & 2 & & \\
\hline Gabon & 1 & Nigeria & 1 & & \\
\hline Germany & 12 & Norway & 5 & & \\
\hline Gibraltar & 2 & Oman & 1 & & \\
\hline Greece & 4 & Pakistan & 3 & & \\
\hline
\end{tabular}




\section{Appendix Table 2 Country Features of Top 20 Countries By Total Claims Size in 2007Q2}

\begin{tabular}{|c|c|c|c|c|c|c|}
\hline Affiliate country & $\begin{array}{c}\text { Total } \\
\text { Claims }^{1} \\
\text { (Billions } \\
\text { USD) }\end{array}$ & $\begin{array}{c}\text { Log } \\
\text { Physical } \\
\text { distance } \\
\text { from NYC }\end{array}$ & $\begin{array}{c}\text { Capital } \\
\text { Account } \\
\text { Openness }\end{array}$ & $\begin{array}{c}\text { Polity } \\
\text { Index }^{4}\end{array}$ & $\mathrm{OFC}^{5}$ & \$Peg \\
\hline United Kingdom & 396.2 & 8.1 & 2.5 & 10 & 0 & 0 \\
\hline Japan & 141.5 & 8.8 & 2.5 & 10 & 0 & 0 \\
\hline Canada & 136.2 & 7.4 & 2.5 & 10 & 0 & 0 \\
\hline Germany & 104.6 & 8.3 & 2.5 & 10 & 0 & 0 \\
\hline Mexico & 89.8 & 7.6 & 1.1 & 8 & 0 & 0 \\
\hline Cayman Islands & 83.5 & 7.8 & 2.5 & & 1 & 1 \\
\hline Korea & 78.9 & 8.8 & -0.1 & 1 & 0 & 0 \\
\hline Netherlands & 70.9 & 8.2 & 2.5 & 10 & 0 & 0 \\
\hline Australia & 64.7 & 9.3 & 1.1 & 10 & 0 & 0 \\
\hline France & 60.5 & 8.2 & 2.5 & 9 & 0 & 0 \\
\hline India & 44.6 & 9.0 & -1.1 & 9 & 0 & 1 \\
\hline Spain & 39.8 & 8.2 & 2.5 & 10 & 0 & 0 \\
\hline Brazil & 36.6 & 8.2 & 0.4 & 8 & 0 & 0 \\
\hline Italy & 35.8 & 8.4 & 2.5 & 10 & 0 & 0 \\
\hline Singapore & 35.4 & 9.2 & 2.5 & -2 & 1 & 0 \\
\hline Ireland & 34.1 & 8.0 & 2.5 & 10 & 1 & 0 \\
\hline Luxembourg & 32.0 & 8.2 & 2.5 & & 1 & 0 \\
\hline China & 29.6 & 8.9 & -1.1 & -7 & 0 & 0 \\
\hline Hong Kong & 25.6 & 9.0 & 2.5 & & 1 & 1 \\
\hline Switzerland & 23.8 & 8.3 & 2.5 & 10 & 0 & 0 \\
\hline
\end{tabular}

${ }^{1}$ Total claims is the sum local claims and cross border claims, from authors' computations based on FFIEC 009 reporting by quarter.

${ }^{2}$ Log physical distance is the great circle distance of the affiliate country from New York City, from Rose and Spiegel (2009).

${ }^{3}$ Index ranges in value from -1.8 in the case of full control to 2.5 in the case of complete liberalization, from Chinn and Ito (2008).

${ }^{4}$ Country ratings on a scale ranging from strongly democratic $(+10)$ to strongly autocratic (-10), from Center for Systemic Peace, Polity IV Project.

${ }^{5}$ Variable takes the value 1 if affiliate country is an offshore financial center, 0 otherwise, from International Monetary Fund.

${ }^{6}$ Variable takes the value 1 if currency of affiliate country is de facto dollar peg or crawl, 0 otherwise, from Ilzetski, Reinhart and Rogoff (2009). 


\section{Appendix Table 3 Net Internal Borrowing Dynamics During the Crisis - Shock 1}

\begin{tabular}{|c|c|c|c|c|c|}
\hline & $\begin{array}{l}(1) \\
\text { OLS }\end{array}$ & $\begin{array}{l}(2) \\
\text { OLS }\end{array}$ & $\begin{array}{l}\text { (3) } \\
\text { OLS }\end{array}$ & $\begin{array}{l}\text { (4) } \\
\text { OLS }\end{array}$ & $\begin{array}{l}\text { (5) } \\
\text { OLS }\end{array}$ \\
\hline$O F C_{j}$ & $\begin{array}{l}-159.0 \\
(105.3)\end{array}$ & $\begin{array}{l}-146.1 \\
(103.7)\end{array}$ & $\begin{array}{c}-92.8 \\
(110.0)\end{array}$ & $\begin{array}{l}-103.7 \\
(112.2)\end{array}$ & $\begin{array}{c}-81.5 \\
(109.2)\end{array}$ \\
\hline kaopen $_{j}$ & $\begin{array}{c}22.4 \\
(48.3)\end{array}$ & $\begin{array}{c}22.3 \\
(48.1)\end{array}$ & $\begin{array}{l}-12.6 \\
(50.6)\end{array}$ & $\begin{array}{c}-6.9 \\
(54.4)\end{array}$ & $\begin{array}{c}-4.7 \\
(53.8)\end{array}$ \\
\hline Idistnyc $_{j}$ & $\begin{array}{c}68.9 \\
(83.6)\end{array}$ & $\begin{array}{c}42.8 \\
(87.0)\end{array}$ & $\begin{array}{c}88.0 \\
(87.8)\end{array}$ & $\begin{array}{c}82.1 \\
(89.4)\end{array}$ & $\begin{array}{c}54.7 \\
(83.0)\end{array}$ \\
\hline exrate $_{j}$ & $\begin{array}{l}-52.3 \\
(50.0)\end{array}$ & $\begin{array}{l}-36.5 \\
(53.6)\end{array}$ & $\begin{array}{l}-49.3 \\
(66.6)\end{array}$ & $\begin{array}{l}-50.3 \\
(69.4)\end{array}$ & $\begin{array}{l}-61.0 \\
(73.3)\end{array}$ \\
\hline ABCP exposure ${ }_{i}$ & & $\begin{array}{l}179.6{ }^{* * *} \\
(20.5)\end{array}$ & $\begin{array}{l}\mathbf{8 4 2 . 9 ^ { * }} \\
(495.4)\end{array}$ & $\begin{array}{c}-2303.3 \\
(2390.9)\end{array}$ & $\begin{array}{l}-\mathbf{4 3 1 3 . 8 ^ { * }} \\
(2315.0)\end{array}$ \\
\hline Exposure $_{i}{ }^{*} O F C_{j}$ & & & $\begin{array}{c}-\mathbf{1 2 0 . 0}^{* * *} \\
(34.3)\end{array}$ & $\begin{array}{c}-107.3^{* * *} \\
(38.3)\end{array}$ & $\begin{array}{l}\mathbf{7 4 . 8}^{*} \\
(38.3)\end{array}$ \\
\hline Exposure $_{i}{ }^{*}$ kaopen $_{j}$ & & & $\begin{array}{l}\mathbf{8 0 . 5}^{* * *} \\
(29.1)\end{array}$ & $\begin{array}{l}\mathbf{8 0 . 2}^{* * * *} \\
(27.6)\end{array}$ & $\begin{array}{c}-2.5 \\
(30.5)\end{array}$ \\
\hline Exposure $_{i}{ }^{*}$ ldistnyc $_{j}$ & & & $\begin{array}{l}-91.9 \\
(61.5)\end{array}$ & $\begin{array}{l}-86.1 \\
(78.5)\end{array}$ & $\begin{array}{c}99.5 \\
(94.4)\end{array}$ \\
\hline Exposure $_{i}{ }^{*}$ exrate $_{j}$ & & & $\begin{array}{c}38.5 \\
(96.9)\end{array}$ & $\begin{array}{c}23.2 \\
(120.4)\end{array}$ & $\begin{array}{c}-22.9 \\
(153.0)\end{array}$ \\
\hline Total asset $_{i}$ & & & & $\begin{array}{l}-0.028 \\
(0.173)\end{array}$ & $\begin{array}{l}-0.105 \\
(0.170)\end{array}$ \\
\hline Liquidity $_{i}$ & & & & $\begin{array}{c}-3087.1 \\
(2257.0)\end{array}$ & $\begin{array}{l}-3499.3 \\
(2175.3)\end{array}$ \\
\hline Solvency $_{i}$ & & & & $\begin{array}{c}-743.7 \\
(1711.9)\end{array}$ & $\begin{array}{c}-220.8 \\
(2071.1)\end{array}$ \\
\hline Herfindhal $_{i}$ & & & & $\begin{array}{c}385.2 \\
(264.6)\end{array}$ & $\begin{array}{c}347.9 \\
(296.8)\end{array}$ \\
\hline $\begin{array}{l}\text { Exposure }_{i}{ }^{*} \text { Total } \\
\text { asset }_{i}\end{array}$ & & & & $\begin{array}{l}-0.353 \\
(0.319)\end{array}$ & $\begin{array}{c}0.106 \\
(0.310)\end{array}$ \\
\hline Exposure $_{i}{ }^{*}$ Liquidity $_{i}$ & & & & $\begin{array}{l}12498.4 \\
(9396.0)\end{array}$ & $\begin{array}{l}14574.2 \\
(8810.0)\end{array}$ \\
\hline Exposure $_{i}{ }^{*}$ Solvency ${ }_{i}$ & & & & $\begin{array}{c}31100.7 \\
(20701.5)\end{array}$ & $\begin{array}{l}33644.4^{*} \\
(19048.0)\end{array}$ \\
\hline $\begin{array}{l}\text { Exposure }_{i}^{*} \\
\text { Herfindhal }_{i} \\
\text { Local finance }_{i j}\end{array}$ & & & & $\begin{array}{c}347.0 \\
(1464.6)\end{array}$ & $\begin{array}{c}-336.9 \\
(1469.9) \\
\mathbf{- 6 8 8 . 3}^{* *} \\
(256.0)\end{array}$ \\
\hline Loan share $_{i j}$ & & & & & $\begin{array}{c}\mathbf{1 0 7 3 9 . 3}^{\text {****}} \\
(1149.8)\end{array}$ \\
\hline $\operatorname{Exp}_{i}{ }^{*}$ Local finance $_{i j}$ & & & & & $\begin{array}{l}-287.6^{*} \\
(154.9)\end{array}$ \\
\hline $\operatorname{Exp}_{i}{ }^{*}$ Loan share ${ }_{i j}$ & & & & & $\begin{array}{l}-141.2 \\
(427.7)\end{array}$ \\
\hline Constant & $\begin{array}{l}-514.2 \\
(750.9) \\
\end{array}$ & $\begin{array}{l}-387.6 \\
(770.6)\end{array}$ & $\begin{array}{c}-719.2 \\
(781.5)\end{array}$ & $\begin{array}{l}-641.3 \\
(880.3) \\
\end{array}$ & $\begin{array}{l}-335.8 \\
(824.6) \\
\end{array}$ \\
\hline Observations & 500 & 500 & 500 & 500 & 500 \\
\hline Adjusted R-squared & 0.003 & 0.017 & 0.017 & 0.011 & 0.220 \\
\hline
\end{tabular}


Appendix Table 4 Net Internal Borrowing Dynamics During the Crisis Full specifications with level and interaction controls

\begin{tabular}{|c|c|c|c|c|}
\hline & $\begin{array}{c}\text { All reporter } \\
\text { Shock } 1\end{array}$ & $\begin{array}{c}\text { U.S.-owned } \\
\text { only } \\
\text { Shock } 1\end{array}$ & $\begin{array}{c}\text { All reporter } \\
\text { Shock } 2\end{array}$ & $\begin{array}{c}\text { U.S.-owned } \\
\text { only } \\
\text { Shock } 2\end{array}$ \\
\hline ABCP exposure $_{i}$ & $\begin{array}{c}-4,357 * \\
(2,319)\end{array}$ & $\begin{array}{c}\mathbf{- 8 , 2 0 8 * *} \\
(3,413)\end{array}$ & $\begin{array}{c}5,370 * * * \\
(1,573)\end{array}$ & $\begin{array}{c}\mathbf{4 , 5 0 5 * *} \\
(1,987)\end{array}$ \\
\hline $\operatorname{Exp}_{i}{ }^{*}$ Local finance $_{i j}$ & $\begin{array}{c}\mathbf{- 6 9 0 . 8} * * * \\
(253.2)\end{array}$ & $\begin{array}{c}-790.2 * * \\
(313.6)\end{array}$ & $\begin{array}{c}1,100 * * * \\
(307.0)\end{array}$ & $\begin{array}{c}1,264 * * * \\
(157.5)\end{array}$ \\
\hline Exp $_{i}^{*}$ Loan share ${ }_{i j}$ & $\begin{array}{c}10,744 * * * \\
(1,154)\end{array}$ & $\begin{array}{c}11,944 * * * \\
(992.7)\end{array}$ & $\begin{array}{c}\mathbf{- 8 , 2 5 8 * * *} \\
(1,429)\end{array}$ & $\begin{array}{c}\mathbf{- 9 , 2 6 4 * * *} \\
(720.5)\end{array}$ \\
\hline Exposure $_{i} * O F C_{j}$ & $\begin{array}{l}80.02 * * \\
(35.54)\end{array}$ & $\begin{array}{l}\text { 66.25** } \\
(26.52)\end{array}$ & $\begin{array}{c}122.5 \\
(200.9)\end{array}$ & $\begin{array}{c}132.5 \\
(226.6)\end{array}$ \\
\hline Exposure $_{i}{ }^{*}$ kaopen $_{i}$ & $\begin{array}{l}-2.408 \\
(23.10)\end{array}$ & $\begin{array}{l}-9.258 \\
(27.77)\end{array}$ & $\begin{array}{c}-83.82 \\
(62.43)\end{array}$ & $\begin{array}{l}-103.6 \\
(64.73)\end{array}$ \\
\hline Exposure $_{i}{ }^{*}$ ldistnyc $_{j}$ & $\begin{array}{c}102.2 \\
(95.41)\end{array}$ & $\begin{array}{c}112.5 \\
(71.38)\end{array}$ & $\begin{array}{c}-507.0 * * * \\
(145.9)\end{array}$ & $\begin{array}{c}\mathbf{- 6 1 6 . 0} * * * \\
(157.9)\end{array}$ \\
\hline Exposure $_{i}{ }^{*}$ exrate $_{i}$ & $\begin{array}{l}-36.30 \\
(138.1)\end{array}$ & $\begin{array}{c}-2.147 \\
(133.0)\end{array}$ & $\begin{array}{c}126.2 \\
(147.6)\end{array}$ & $\begin{array}{c}129.2 \\
(145.1)\end{array}$ \\
\hline Exposure $_{i}{ }^{*}$ Total asset $_{i}$ & $\begin{array}{c}0.105 \\
(0.307)\end{array}$ & $\begin{array}{l}-0.390 \\
(1.392)\end{array}$ & $\begin{array}{c}-\mathbf{0 . 7 4 4} * * * \\
(0.133)\end{array}$ & $\begin{array}{l}\mathbf{- 0 . 7 4 5 *} \\
(0.431)\end{array}$ \\
\hline Exposure $_{i}{ }^{*}$ Liquidity $_{i}$ & $\begin{array}{l}14,658 \\
(8,767)\end{array}$ & $\begin{array}{c}\text { 31,183** } \\
(14,654)\end{array}$ & $\begin{array}{c}-4,029 \\
(3,082)\end{array}$ & $\begin{array}{c}1,707 \\
(2,631)\end{array}$ \\
\hline Exposure $_{i}{ }^{*}$ Solvency $_{i}$ & $\begin{array}{l}33,771^{*} \\
(18,940)\end{array}$ & $\begin{array}{c}56,784 \\
(34,738)\end{array}$ & $\begin{array}{l}-6,125 \\
(5,589)\end{array}$ & $\begin{array}{c}13,568 \\
(12,884)\end{array}$ \\
\hline Exposure $_{i}{ }^{*}$ Herfindhal $_{i}$ & $\begin{array}{c}-292.2 \\
(1,448)\end{array}$ & $\begin{array}{c}6,192 \\
(22,618)\end{array}$ & $\begin{array}{c}514.2 \\
(1,100)\end{array}$ & $\begin{array}{l}-1,250 \\
(5,312)\end{array}$ \\
\hline$O F C_{j}$ & $\begin{array}{l}-84.68 \\
(101.6)\end{array}$ & $\begin{array}{l}-79.24 \\
(114.6)\end{array}$ & $\begin{array}{c}82.34 \\
(94.66)\end{array}$ & $\begin{array}{c}147.6 \\
(113.8)\end{array}$ \\
\hline kaopen $_{i}$ & $\begin{array}{l}-1.953 \\
(50.63)\end{array}$ & $\begin{array}{c}19.91 \\
(71.14)\end{array}$ & $\begin{array}{l}-2.348 \\
(30.68)\end{array}$ & $\begin{array}{l}-17.57 \\
(42.22)\end{array}$ \\
\hline ldistnyc $_{j}$ & $\begin{array}{c}52.47 \\
(83.04)\end{array}$ & $\begin{array}{c}127.2 \\
(117.2)\end{array}$ & $\begin{array}{c}11.16 \\
(54.73)\end{array}$ & $\begin{array}{l}-8.939 \\
(80.67)\end{array}$ \\
\hline exrate $_{i}$ & $\begin{array}{l}-51.85 \\
(65.32)\end{array}$ & $\begin{array}{l}-127.5^{*} \\
(68.49)\end{array}$ & $\begin{array}{l}-56.30 \\
(95.51)\end{array}$ & $\begin{array}{l}-66.27 \\
(118.1)\end{array}$ \\
\hline 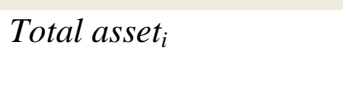 & $\begin{array}{l}-0.104 \\
(0.169)\end{array}$ & $\begin{array}{c}0.117 \\
(0.234)\end{array}$ & $\begin{array}{l}\mathbf{0 . 4 4 0} * * * \\
(0.0885)\end{array}$ & $\begin{array}{l}\text { 0.335* } \\
(0.171)\end{array}$ \\
\hline Liquidity $_{i}$ & $\begin{array}{l}-3,522 \\
(2,162)\end{array}$ & $\begin{array}{l}-7,395^{*} \\
(3,593)\end{array}$ & $\begin{array}{c}713.1 \\
(640.1)\end{array}$ & $\begin{array}{l}-532.6 \\
(736.4)\end{array}$ \\
\hline Solvency $_{i}$ & $\begin{array}{l}-218.7 \\
(2,061)\end{array}$ & $\begin{array}{l}-2,098 \\
(2,579)\end{array}$ & $\begin{array}{c}982.0 \\
(912.9)\end{array}$ & $\begin{array}{c}1,581 \\
(1,943)\end{array}$ \\
\hline Herfindhal $_{i}$ & $\begin{array}{c}337.4 \\
(295.6)\end{array}$ & $\begin{array}{c}275.2 \\
(212.6)\end{array}$ & $\begin{array}{l}-83.05 \\
(235.4)\end{array}$ & $\begin{array}{l}-56.02 \\
(348.4)\end{array}$ \\
\hline Local finance $_{i j}$ & $\begin{array}{l}-286.4^{*} \\
(154.8)\end{array}$ & $\begin{array}{c}-419.0 * \\
(208.2)\end{array}$ & $\begin{array}{c}43.76 \\
(161.2)\end{array}$ & $\begin{array}{c}64.84 \\
(166.7)\end{array}$ \\
\hline Loan share $_{i j}$ & $\begin{array}{l}-142.7 \\
(427.7)\end{array}$ & $\begin{array}{c}273.2 \\
(571.2)\end{array}$ & $\begin{array}{l}\mathbf{1 , 6 4 7 * *} \\
(812.1)\end{array}$ & $\begin{array}{c}1,929 \\
(1,232)\end{array}$ \\
\hline Constant & $\begin{array}{l}-324.1 \\
(822.2)\end{array}$ & $\begin{array}{l}-805.7 \\
(1,144)\end{array}$ & $\begin{array}{l}-387.9 \\
(496.1)\end{array}$ & $\begin{array}{l}-237.5 \\
(755.8)\end{array}$ \\
\hline $\begin{array}{l}\text { Observations } \\
\text { R-squared }\end{array}$ & $\begin{array}{c}500 \\
0.253\end{array}$ & $\begin{array}{c}423 \\
0.305\end{array}$ & $\begin{array}{c}513 \\
0.213\end{array}$ & $\begin{array}{c}438 \\
0.250\end{array}$ \\
\hline
\end{tabular}

